\title{
Land tenure policy and off-farm employment in rural China
}

\author{
Hongqin Chang ${ }^{*}$, Ping Ai and Yuan Li
}

\author{
* Correspondence: \\ changhongqin@126.com \\ Taiyuan University of Technology, \\ Taiyuan, China
}

\begin{abstract}
Using the data from the three waves (1995, 2002, and 2008) of the Chinese Household Income Project (CHIP), this paper investigates the impact of land tenure security on farmers' labor market outcomes in rural China. To identify the effect of land tenure security, this paper used difference-in-differences strategy to control for time invariant heterogeneity and a number of observed time-varying economic characteristics for its validity. The paper finds that in response to more security land rights, both women and men increase their probability of wage employment participation.

JEL Classification: 015, J61, Q15, R23

Keywords: Land tenure, Off-farm, Rural China
\end{abstract}

\section{Introduction}

\subsection{Context of the study}

\subsubsection{Household responsibility system and land security rights in China}

Before the land tenure reform in 1978, China carried out collective farming, which was characterized by collective ownership and unified collective operation. Property rights were centrally controlled, and the most severe problem with collective farming was inefficiency.

The Household Responsibility System (HRS) had implemented in rural China in 1979 and was essentially completed by the end of 1983 (Lin 1992). Under the HRS, landholdings were distributed among households in a substantially egalitarian fashion (Burgess 1998). Practically, no rural households were landless (Zhang 2001). The underlying idea behind this institutional scheme was to give rural households relative freedom in their productive choices and to grant them secure land-use rights as a means of promoting individual investment. However, land ownership remains in the hands of collective village authorities; therefore, it could not be transferred between households, and land-use rights were contracted to the farmers for a short period of 1 to 2 years. In this context, security of rights over land depends mainly on two factors: the village authorities' land management and the contractual status of the plot.

Today, under the framework of the HRS, there are five major tenure types in China (Brandt et al. 2002): responsibility land, grain ration land, contract land, private plot, and reclaimed land. Responsibility land is allocated on the basis of the number of family members, the number of laborers in each family, or the desire and ability of the

(c) The Author(s). 2018 Open Access This article is distributed under the terms of the Creative Commons Attribution 4.0 International License (http://creativecommons.org/licenses/by/4.0/), which permits unrestricted use, distribution, and reproduction in any medium, provided you give appropriate credit to the original author(s) and the source, provide a link to the Creative Commons license, and indicate if changes were made. 
household to engage in agricultural production. Grain ration land is typically allocated on the basis of household size to ensure that each household produces enough for its own consumption needs. The use of the land does not usually entail quotas or other obligations. A small amount of land was provided to rural households for private plots during the period of collective agriculture, and farmers retained this land when China reverted to family farming. Contract land is rented to households by the villages for a fixed cash payment. The length of these contracts varies considerably from community to community. Farmers can also acquire use rights to reclaimed land that was previously uncultivated. There are usually no quotas or fees tied to the use of the land (Brandt et al. 2002, p. 73-74). Each tenure type encompasses a different set of rights and obligations for rural households and guarantees a different level of security. A household's use rights over private plot and grain ration land can be considered comparatively secure and stable. Responsibility land, contract land, and reclaimed land, on the other hand, impose various obligations, such as the delivery of a mandatory quota of grain to the state at below-market prices. Those three types of land can be quite easily transferred and reallocated among households by the collective. A survey by the State Statistical Bureau in 1992 demonstrated that grain ration land only made up 8.4\% of cultivated area, and responsibility land covered $84.5 \%$ of cultivated land (Cheng and Tsang 1996).

Although the HRS intended to implement the land-use rights through a contractual framework, the contracts, in particular, the contract's duration, have not been respected by village collective authorities, who have periodically approved reallocation of land among household villagers. As discussed in Jacoby et al. (2002), reallocation of lands is promoted by local governments because of the following: first, following the demographic change within households, it helps to keep an egalitarian distribution of land (Kung, 1994); second, it reduces the inefficiencies often created by the distribution of land which happens with households' demographic changes, especially in contexts with land rental and labor markets failure (Li 1999; Benjamin and Brandt 2000); and third, it represents for local governments a tool to collect taxes and achieve production quotas (Rozelle and Li 1998).

Periodic land reallocation has created uncertainty in rural households about the durability of land contracts and the risk of land expropriation in the future, thereby discouraging some households to decide to allocate labor to migration, to commit labor to off-farm employment, or to rent land.

\subsubsection{Rural land contracting law}

Realizing that frequent land reallocation and abusive land requisition has led to the insecurity of the land-use rights of farmers, the government has taken various action to promote land tenure security (Tao and Xu 2007). In 2002, China passed the Rural Land Contracting Law (RLCL) into law (Li 2003). This law goes beyond previous attempts to secure the land rights of farmers. ${ }^{1}$ The RLCL requires farmers and collectives be issued with written contracts and certificates to confirm their land-use rights. These land contracts have a duration of 30 years. The RLCL focuses on four areas, namely (i) a stricter definition of land rights as property rights rather than just private contracts, (ii) a ban on large-scale reallocations of land and limiting small-scale readjustments with clear conditions, (iii) permitting land transfer between households, and (iv) a commitment to issuance of land documents (Deininger et al. 2012). 
The RLCL provides a legal basis for issues relating to tenure security, marketability, and enforcement of rural household land rights that had previously been dealt with only through administrative means. By giving a legal backing to secure 30-year rights and eliminating the scope for further readjustment of land, the RLCL aims to promote investment, diversification, and productivity. Land rights remain with the household even if some members change their registration status. A second goal of the RLCL is to create a basis for more impersonal transfers of land. Such transfers are of increased relevance to ensure adequate land utilization since, with migration or development of the rural non-farm economy, households respond to non-farm opportunities. For this purpose, the law allows land rights to be exchanged and to be leased, transferred, and assigned to others much more easily than was possible before (Deininger et al. 2004). The law also emphasizes the equality of men and women, stipulating that in case of marriage, divorce, or death of the husband, the rights to land of the spouses are maintained unless they receive a new land allocation in their new village.

Table 1 presents the security land rights by villages for those years available in our data set (i.e., 1995, 2002, 2008). Land security at village level is measured by means of an indicator that combines information on the share of grain ration land relative to the village total land and whether or not the village retained some flexible land. Section 4.1 provides details on the data set and the construction of the security land indicator. The table shows a total of 795 villages in 1995, and 847 in 2002, among which there are 33 and $53 \%$ of villages, respectively, with higher security land rights. In 2008, the numbers of villages is 271 , and the villages with higher security land increased to $91 \%$. The statistics summary shows that after the policy change, there was an improvement in land security rights across villages. Thus, the empirical analysis in this paper is based on a comparison across time of labor market outcomes for adults in villages with (i.e., treatment group) and without (i.e., comparison group) land security rights.

\subsection{Research questions and objectives}

This paper contributes to this recent but growing literature by analyzing the relationship between land security and off-farm employment in rural China, focusing on women's behavior. This research issue is relevant because although women have participated in off-farm activities at rates below those of men, participation rates have risen steadily since 1995. In fact, during the period 1995-2011, the participation rate of women in the off-farm sector rose faster than that of men (Li et al. 2013). Therefore, it is important to explore the extent to which the institutional changes in land tenure, which occurred in recent decades, have contributed to explaining this general pattern in off-farm employment of women in rural China.

Table 1 Summary statistics of security land by villages

\begin{tabular}{|c|c|c|c|c|c|c|}
\hline \multirow[t]{2}{*}{ Year } & \multicolumn{2}{|l|}{1995} & \multicolumn{2}{|l|}{2002} & \multicolumn{2}{|l|}{2008} \\
\hline & Freq. & Percent & Freq. & Percent & Freq. & Percent \\
\hline Villages with higher security land & 533 & 32.96 & 402 & 52.54 & 247 & 91.14 \\
\hline Villages with lower security land & 262 & 67.04 & 445 & 47.46 & 24 & 8.86 \\
\hline Number of villages & 795 & 100 & 847 & 100 & 271 & 100 \\
\hline
\end{tabular}

Source: The following data sources, if not specifically stated, are from CHIP 
To explore the link between land security and off-farm employment of women, this study focuses on a major land-policy change in China, the RLCL which had passed in 2002, sought to improve land right of farmers. The RLCL required farmers and collectives be issued with written contracts and certificates to confirm their land-use rights, and the duration of the land contract was to be set at 30 years. One of the consequences of this policy change was the reduction of farmers' risk of losing land rights in future periods due to migration. As a result, incentives promote men and women in rural households to move into off-farm employment and to derive their income from non-agricultural sources.

To identify the effect of the RLCL on farmers' labor market outcomes, this paper uses a difference-in-differences strategy to control for time invariant heterogeneity. The data used for the empirical analysis were derived from the Chinese Household Income Project (CHIP) household survey, for the waves of 1995, 2002, and 2008. We explore the impacts of land security rights on the following market outcomes: employment, farm work, off-farm work, wage employment, and self-employment. As highlighted, the main analysis focuses on women's outcomes in labor market; however, for comparative proposes, behavioral response of men to the RLCL is also explored. We found that improvement in land rights security derived from the RLCL has a positive influence on both women's and men's labor market behavior. In terms of the pre-policy average, employment increases $5.9 \%$ for women and $3.9 \%$ for men, and off-farm employment increases $40 \%$ for women and $28 \%$ for men.

This paper contributes to the literature on the issue of land rights insecurity in developing countries. While most of the literature has focused on the impact of land rights on investment and productivity (e.g., Carter and Yao 1999; Jacoby et al. 2002; Deininger and Jin 2003; Goldstein and Udry 2008), less is known about its effect on household decision making as migration (e.g., Mullan et al. 2011) or employment decisions(e.g., Field 2007). An additional contribution of this paper is to shed light on an alternative way in which land tenure may affect household welfare; that is, by encouraging women to be engaged in off-farm activities with higher income return relative to farm work, the RLCL may increase women's economic empowerment and their ability to influence intra household decisions. ${ }^{2}$ In rural China, women, especially those who were married, are considered the group that should stay at home and be committed to care for the elderly and children, as well as undertake the task of agricultural production (Wang 1999; Knight and Song 2003; Chang et al. 2011). Although rising, their labor force participation and income lag behind of men in off-farm employment (Chan and Senser 1997; Solinger 1999; Maurer-Fazio 1999; Song and Jiggins 2000; Li 2001; De Brauw et al. 2002; Shi et al. 2007).

This study also contributes to the literature on China and labor market transition, in particular in rural areas, by empirically exploring the impact of rural land tenure and off-farm employment. This issue is relevant for the Chinese case due to the rapid increase in off-farm employment, particularly for women. This was experienced during the last three decades, a period which also involved major institutional changes in land arrangements. Although this topic is highly important, empirical research is still scarce. For instance, Kung and Lee (2001) and Shi et al. (2007) document that the development of land rental markets has encouraged off-farm employment; however, none of these studies directly analyze the impact of land insecurity on off-farm employment. 
This is the case of Lohmar (1999), who seeks to determine whether land insecurity in China deters workers in farm households from off-farm employment and finds that households in villages with relatively high insecurity are less likely to participate in such types of employment activities. In the present paper, we proceed by using a quasi-experimental design to analyze whether the recent land-policy changes in China, which improved land security rights of farmers, have increased employment in off-farm activities. Our results suggest that the positive impact of these types of policies on off-farm employment, such as the RLCL, could be a factor that explains the increasing tendency observed in the overall employment rate in off-farm activities in China, mainly among women.

\section{Literature review}

China's rural economy has undergone radical change since the onset of economic reforms in 1978. The implementation of the HRS in 1979, which replaced the commune system, significantly improved farmers' work incentives by giving them relative freedom in their productive choices and granting secure land-use rights as a means of promoting productive investment (Rozelle et al. 1999). Li et al. (1998) show that in rural China, the production behavior of farmers is affected by the type of land tenure and the associated property rights. For instance, the right to use land for long periods of time encourages the use of land-saving investments, while the lack of private property rights can be seen as a hindrance to efficient allocation and use of land (Dong 1996). In addition, the emergence of land rental market after almost two decades of rural reforms (Kung 2002), and the fact that households renting land have achieved higher land productivity than their counterparts, indicates that land rental transactions have increased aggregate agricultural production in China (Lohmar et al. 2001).

The increasing productivity of the agricultural sector in rural China, in addition to a decreased demand for labor in this area and an increased wage differential between rural and urban areas, has provided strong incentive for rural labor to shift to off-farm employment in recent decades (Zhao 1999). Estimates suggest that offfarm (rural) employment in China rose from less than 150 million in 1995 to more than 250 million in 2004, that is, a growth in off-farm employment of more than 100 million people. By 2011, 61\% of rural inhabitants were participating in offfarm work (nearly 310 million rural individuals), which is a rise of approximately 20\% between 2004 and 2011 ( $\mathrm{Li}$ et al. 2013).

The patterns have motivated recent empirical research to focus on the relationship between land property rights, migration, off-farm activities, and employment. For instance, De La Rupelle et al. (2009) argue that insecure land rights influence households' labor allocation and shorten migration duration, preventing rural people from moving out of agriculture and out of rural areas. The authors test this hypothesis by exploiting variation in the intensity of land rights insecurity under the HRS across and within villages by using data from the Chinese Household Income Project (CHIP) household survey. ${ }^{3}$ By exploiting the source of variation, De La Rupelle et al. (2009) show that migration behavior varies with the contractual structure of land holdings. When land is manipulated by village authorities, households with more secure grain ration land plots can afford to spend more time migrating. Similarly, Mullan et al. (2011) analyze the role of incomplete rural property rights in the migration decisions of rural households by using independent-based household surveys and self-reported information on land 
tenure and find that tenure insecurity reduces migration. Similar qualitative conclusions arise from the study of $\mathrm{Mu}$ and Giles (2014). Based on time variation in land reallocation (i.e., a more insecure land arrangement) across villages in 1995 and 2003 period, the authors find that farmers reduced their probability of migrating in response to a higher probability of village-wide land reallocation.

How does the RLCL affect farmers' off-farm employment decisions? Our analysis is based upon the description by Besley (1995) and Mullen et al. (2008) of the link between land rights and investment decisions, who discuss two relevant arguments according to which land management arrangements could influence off-farm choice decisions in the context of China, in particular, the decision by rural households to migrate and participate in outside labor markets.

First, migration is associated with a risk of expropriation since it entails a decrease in household size, which may induce the redistribution of some of the household land in order to maintain egalitarian land holdings (Rozelle and Li 1998). The RLCL imposes a ban on large-scale reallocations of land and limited small-scale readjustments. It reduced farmers' worry about their risk of losing land rights at a future time if they decided to migrate to off-farm activities. Second, migration is encouraged by the development of land exchange rights. The RLCL detailed the right to lease, assign, exchange, and carry out other transactions with land contracts. Thus, this policy change was expected to facilitate market transfers and improve the marketability of land rights. Land transfers permit households with higher marginal productivities of land to acquire land from households with lower marginal productivities, and induce a better allocation of household labor endowments in response to outside employment opportunities, such as those in off-farm activities.

As consequence of a plausible reduction of barriers to migration out of rural areas, due to the improvement in land security rights as a result of the RLCL, it was expected that the policy change would also have a positive effect on off-farm labor markets. In particular, the main hypothesis to be empirically tested in our work is that the improvement in land security rights, due to the RLCL, had a positive effect on overall off-farm employment. However, the incentives of the reform probably heterogeneously affected different categories of workers. Indeed, most of the self-employed individuals were operating small family firms that were labor intensive and used little capital. As a consequence, the risk of land insecurity for firm owners was much higher than for those in the wage-earning sector. Therefore, we expect that the increase in off-farm employment after implementation of RLCL was driven mostly by an increase in wage employment rather than a growth in self-employment. ${ }^{4}$

Should we expect that both women and men respond similar to the RLCL? We expect a certain degree of heterogeneity in response by gender, not because either men or women in rural households have faced different incentives from the RLCL but because probably the propensity to respond is heterogeneous (i.e., because the incidence may vary across groups). While a large reduction of the time spent in agriculture activities with a significant increase in off-farm work have been documented for both men and women, since the land tenure reforms began, the participation rate of men working full time in agriculture has been lower throughout the 1980s-2000s. This is due to their earlier and larger shift into the off-farm sector. For instance, in the 2000s, men between the ages of 30 and 50 participated in the off-farm labor force at rates more than $40 \%$ 
points higher than women ( $\mathrm{Li}$ et al. 2013). Thus, this gap in off-farm employment rate may have generated a higher impact of the RLCL on the employment of women in off-farm activities relative to men. Actually, Li et al. (2013) document that the participation rate of women as full-time farm workers have declined faster than that of men during this period, mainly the 1990s, and off-farm participation rate has risen faster for women than for men.

In the remainder of the paper, we will use the discussion above to guide our empirical investigation of the impact of the RLCL on labor market outcomes of both men and women. Specifically, we look at the impacts of improvement in land security rights due to the RLCL on the following outcomes: employment, farm work, off-farm work, wage employment, and self-employment.

\section{Methodology and data}

\subsection{Data and sample construction}

The empirical analysis in this study is derived from cross-sectional data from the Chinese Household Income Project (CHIP) household survey for years 1995, 2002, and 2008 and thus covers the period before (1995 and 2002) and after the RLCL implementation (2008). ${ }^{5}$ The purpose of this survey was to measure the distribution of personal income and related economic factors in both rural and urban areas of China. Data was collected through a series of questionnaire-based interviews conducted in rural and urban areas and supported by the China National Bureau of Statistics (NBS) and the Institute for the Study of Labor (IZA).

The CHIP survey covered nine provinces in China. They are Hebei, Jiangsu, Zhejiang, and Guangdong from eastern China; Anhui, Henan, and Hubei from central China; and Chongqing and Sichuan from western China. The sample was chosen according to NBS data in order to be representative of the whole Chinese population. The survey contains detailed information on incomes and expenditures, employment status, family structure, and social and economic characteristics at both personal and household level. The information on individual and household characteristics in the survey is complemented by extensive data on village-level characteristics. We use this information to measure the impact of improvements of land security due to the RLCL on off-farm employment, as described below.

For the original sampling, the CHIP1995 was selected from significantly larger samples drawn by the State Statistical Bureau and contained 7998 households and 34,739 individuals interviewed across 802 villages, which cover 19 provinces in China. CHIP2002 interviewed 37,969 people, from 9200 households distributed across 961 villages, which cover 22 provinces in China. CHIP 2008 contained 7990 households and 32,139 individuals interviewed across 355 villages, which cover 9 provinces in China. All of them include the following nine provinces: Hebei, Jiangsu, Zhejiang, Guangdong, Anhui, Henan, Hubei, Chongqing, and Sichuan. The number of villages included in CHIP 2008 shows a larger decline, but the number of households and individuals interviewed in 2008 has basically not changed. In this paper, the sample excludes the retired and those who were studying full time during the survey's reference period. Taking all of these restrictions into account and omitting observations with missing information yields a sample of 66,779 
observations for individuals aged 16 to 65 years old: 28,813 females and 31,580 males. The statistical description of variables is shown in Table 11 in the Appendix.

The key variable in our study is a measure for land right security indicating treatment status at village level. Following previous studies (e.g., De La Rupelle et al. 2009), we relied on the variation of security rights across villages, depending on each village's collective management of land. However, an important limitation of constructing a "homogenous" measure for land security is the CHIP questionnaire that asks for this type of information by using different specific questions across the 3 years of the survey considered for the analysis. To address this issue, in this study, we use two comparable variables to indicate the village-level dimension of security. For the years of 1995 and 2002, the land security measure is defined by using a variable which measures the share of grain ration land in total land at the village level. Grain ration land is intended to enable farmers to retain some land "to secure their food supply" (Cheng and Tsang 1996). Higher share of grain ration land in total land at the village level means there are more security rights for the village farmers. For the year of 2008, since the (continuous) variable indicating grain rotation is unavailable in the CHIP, the variable we use to measure land security at village level is whether the village has retained some land for adjustment (which is often translated as "flexible land"). The existence of flexible land means that there is room for land reallocation by part of the village leaders, i.e., the farmers have to take into account that their land can be redistributed to other members of the village (Cheng and Tsang 1996). Therefore, due to the data restrictions discussed above, we construct the measure for land security at village level (i.e., a variable for treatment status, as a binary indicator variable). In particular, for the years of 1995 and 2002, the indicator for land security at village level is coded as one if the share of grain ration land in total land at the village dimension is above the mean value of the year; meanwhile, for the year of 2008, it is coded as one if the village retained some flexible land that year.

In order to verify our results are not (strictly) dependent on the information used to construct the land security indicator, we exploit the fact that the variable of "flexible land" for the CHIP2002 is also available and conduct some robustness exercises. Specifically, we construct "placebo-treatment status" by using the information about flexible land instead of grain rotation for 2002. First, we check the percentage of coincidences in the assignment of villages to treatment by using the original and "placebo" treatment status definition. Results show a high share of coincidence, in the order of 41.91 and $52.54 \%$. Second, we perform the main estimates shown in the empirical analysis but using the placebo-treatment status definition as an indicator for treatment in the regression specification. The results of this exercise are qualitatively similar to those obtained by using the original definition of treatment, as depicted in Tables 15 and 16 in the Appendix section.

\subsection{Identification assumptions and econometric strategy}

The empirical work in this paper aims to identify the causal effect of land security on farmers' labor market outcomes in villages that had higher land security rights since the RLCL was implemented in 2002. (Figs. 1 and 2)

In this paper, the major concern is that those villages that chose improving land security could be different from villages that chose not to improve land security 


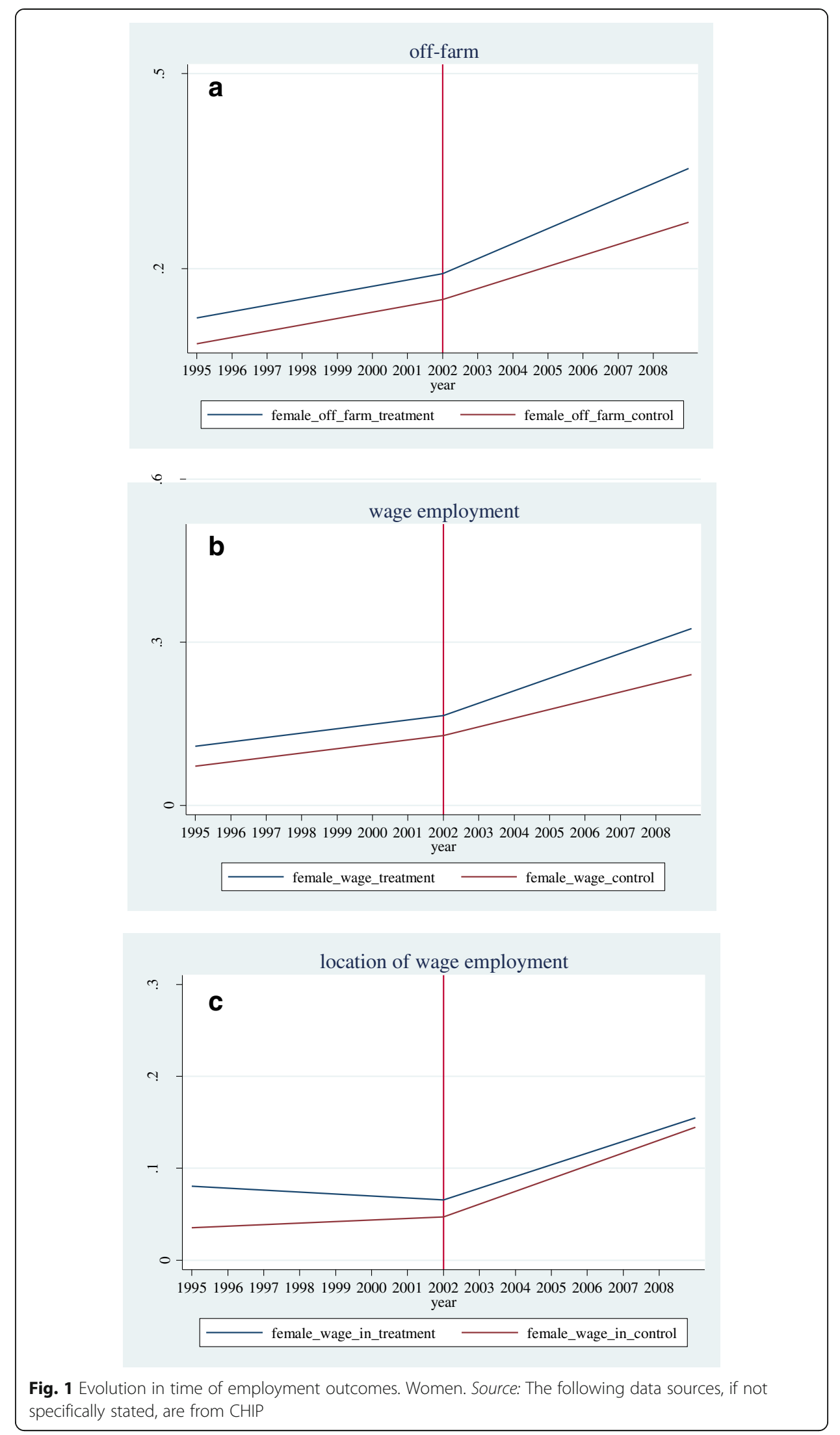



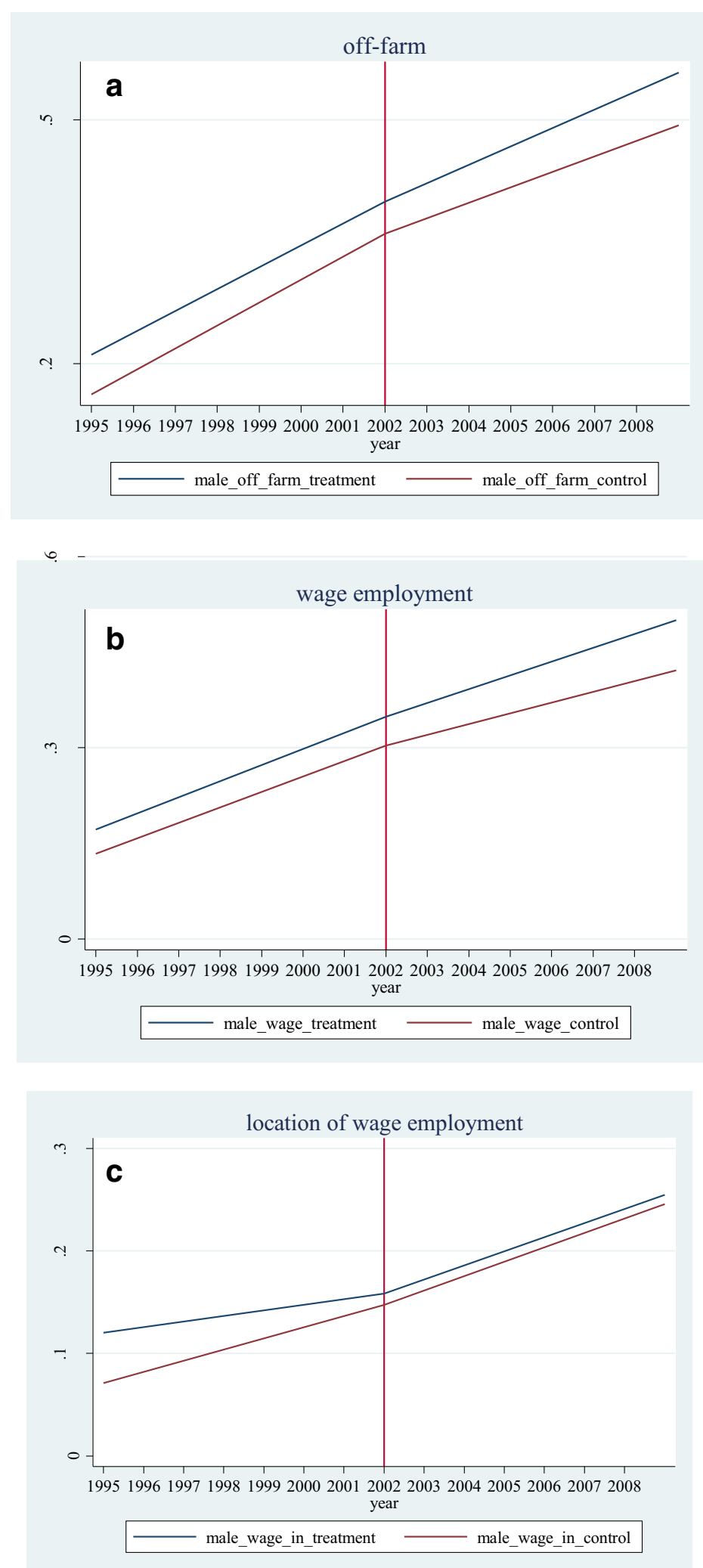

Fig. 2 Evolution in time of employment outcomes. Men. Source: The following data sources, if not specifically stated, are from CHIP 
and that this difference may be correlated with labor market outcomes. If households have more secure land, they can afford to spend more time being engaged in off-farm work (Brandt et al. 2002). However, many of the unobserved characteristics that may confound identification by using a simpler OLS strategy not only vary across villages but also are fixed over time. For example, such types of timeinvariant factors are the preferences of village authorities to redistribute land, at least in a relatively short-time period as that characterized by our analysis.

In order to control for time-invariant unobserved factors, we use a difference-indifferences approach to evaluate the policy's effect (Angrist and Krueger 1999), which compares the change in outcomes in the treatment group before and after the RLCL was implemented to the change in outcomes in the control group. The latter group is assumed to capture the counter factual trend for the treatment group which would have been observed in the absence of the policy change. The treatment group consists of individuals aged 16 to 65 in villages that have higher security rights (i.e., the village share of grain ration land in total land is above the mean value for years 1995 and 2002, and there is no flexible land in the collective for the year of 2008). The comparison group consists of individuals in the same age range whose village has land insecurity, as defined above. The empirical analysis therefore compares the off-farm labor market participation of women or men in the village having higher land security with land insecurity. By comparing changes, we control for unobserved time-invariant village characteristics that might be correlated with the land security as well as off-farm employment decision.

The following is the difference-in-differences specification with controls on which most of the estimates in this paper are based:

$$
\begin{aligned}
Y_{i j t}= & \alpha+\beta_{0} \text { year95 }+\beta_{1} \text { year08 }+\delta \text { landsecurity }_{j t}+\gamma_{0}{\text { year } 95 \times \text { landsecurity }_{j t}} \\
& +\gamma_{1} \text { year08 } \times \text { landsecurity }_{j t}+X_{i j t}^{\prime} \lambda+\theta_{t}+\phi_{j}+\varepsilon_{i j t}
\end{aligned}
$$

where $i$ indexes individuals, $j$ village, and $t$ time. The variable $Y_{i j t}$ is one of the outcomes of interest; land security ${ }_{j t}$ is an indicator variable for villages in the treatment group, coded as one if the village has higher land security and zero otherwise; year95 is a dummy equal to one before the RLCL and zero otherwise; year08 is a dummy equal to one after the RLCL was implemented and zero otherwise; and year08 $\times$ land security $y_{j t}$ is the interaction between the two variables, which captures the difference-in-differences treatment effect. Year $95 \times$ land security $y_{j t}$ is the interaction between the variables of year95 and land security ${ }_{j t}$, which controls for possible different pre-trends between the control and treatment groups. The $X_{i j t}$ matrix contains individual-specific variables and household and village variables to condition the differences in trends to observable characteristics. The individual covariates include age, education level, and marital status; the household covariates include land holding by household measured by the total area used for agricultural activities, asset used for agriculture measured by the balance of family financial assets, and the household demographic composition; finally, controls at village-level dimension include the village consumption level and per capital income. ${ }^{6} \theta_{t}$ is a time effect common to all villages in time $\mathrm{t}$, and $\phi_{j}$ is a fixed effect unique to the village. The $\varepsilon_{i j t}$ is an individual time-varying error. 
The analysis is based on the set of labor market outcomes of interest directly related to the expected effects discussed in the section on theoretical predictions. Those outcomes include overall employment, farm work, off-farm employment, wage employment, and self-employment. Through the entire empirical analysis, the difference-indifferences results are showed separately for men and women.

The second identification assumption is that the composition of each group remained constant over the period under study. This assumption would be violated, for instance, if the treatment group expanded over time and incorporated individuals with different characteristics. Although our regression equation includes controls for a broad set of individual and household characteristics, this may not be enough to control for potential differences in group-specific compositional changes over time. In Section 4.4, we will test whether the possible compositional effect has influenced the results.

Tables 2 and 3 present the statistics summary of some of the main variables by treatment status before and after the policy change for women and men in the sample. The statistics indicate that both women and men in the two groups were reasonably similar in terms of age, education, legal status, and other main socioeconomic characteristics. Most importantly, the last column in the table presents the difference between the preand post-reform changes for the two groups, which indicates only a few statistically

Table 2 Summary statistics. Women

\begin{tabular}{|c|c|c|c|c|c|c|c|c|c|}
\hline & \multicolumn{4}{|c|}{ Control } & \multicolumn{4}{|c|}{ Treatment } & \multirow{3}{*}{$\begin{array}{l}\text { Difference-in- } \\
\text { differences } \\
\text { Land security } \times \text { policy }\end{array}$} \\
\hline & \multicolumn{2}{|c|}{ Pre-reform } & \multicolumn{2}{|c|}{ Post-reform } & \multicolumn{2}{|c|}{ Pre-reform } & \multicolumn{2}{|c|}{ Post-reform } & \\
\hline & Mean & S.D. & $\overline{\text { Mean }}$ & S.D. & $\overline{\text { Mean }}$ & S.D. & $\overline{\text { Mean }}$ & S.D. & \\
\hline Observations & \multicolumn{2}{|c|}{12,130} & \multicolumn{2}{|c|}{512} & \multicolumn{2}{|c|}{9294} & \multicolumn{2}{|c|}{6877} & 28,813 \\
\hline Age & 35.47 & 13.02 & 41.20 & 12.39 & 35.79 & 12.99 & 40.07 & 12.78 & -0.560 \\
\hline Education level & 5.70 & 3.28 & 7.24 & 2.43 & 5.97 & 3.20 & 7.15 & 2.16 & $0.270^{*}$ \\
\hline Legal status & 0.93 & 0.33 & 0.88 & 0.36 & 0.86 & 0.38 & 0.85 & 0.39 & -0.010 \\
\hline Log land & 1.95 & 0.76 & 1.09 & 1.35 & 1.79 & 0.75 & 1.28 & 0.93 & $0.460^{* * * *}$ \\
\hline Log asset & 7.48 & 1.28 & 8.08 & 1.39 & 7.56 & 1.27 & 8.14 & 1.38 & $0.260^{* * *}$ \\
\hline Log per capita income & 8.02 & 0.54 & 8.76 & 0.42 & 8.01 & 0.59 & 8.58 & 0.51 & $-0.060^{* *}$ \\
\hline Log consumption_level & 8.03 & 0.04 & 8.56 & 0.04 & 8.00 & 0.03 & 8.56 & 0.04 & $-0.003^{*}$ \\
\hline Girls aged 6 or younger & 12.08 & 35.28 & 9.38 & 29.84 & 11.64 & 34.15 & 11.33 & 34.04 & 0.020 \\
\hline Boys aged 6 or younger & 14.86 & 38.17 & 8.40 & 27.76 & 13.96 & 36.17 & 13.92 & 36.65 & $0.060^{* * *}$ \\
\hline Boys aged 7-14 & 32.62 & 56.56 & 15.04 & 37.39 & 28.64 & 51.97 & 18.12 & 41.99 & 0.030 \\
\hline Girls aged 7-14 & 27.30 & 53.97 & 11.52 & 33.75 & 22.75 & 49.02 & 14.53 & 39.04 & 0.030 \\
\hline Women aged 15-25 & 79.47 & 86.63 & 52.73 & 72.91 & 76.99 & 84.98 & 59.27 & 76.25 & $0.070^{*}$ \\
\hline Men aged 15-25 & 56.45 & 68.78 & 44.34 & 61.67 & 55.23 & 70.22 & 44.93 & 62.43 & 0.010 \\
\hline Women aged 26-39 & 39.23 & 50.10 & 38.28 & 50.63 & 41.33 & 51.22 & 44.31 & 56.55 & $0.060^{* *}$ \\
\hline Men aged 26-39 & 39.15 & 52.08 & 42.58 & 55.11 & 41.32 & 53.60 & 46.59 & 59.90 & 0.040 \\
\hline Women aged $40-50$ & 47.11 & 50.08 & 44.92 & 50.96 & 46.73 & 49.96 & 43.86 & 49.62 & -0.010 \\
\hline Men aged 40-50 & 43.68 & 49.80 & 39.06 & 48.84 & 43.53 & 49.76 & 38.05 & 48.76 & -0.010 \\
\hline Women aged 51-69 & 28.43 & 45.54 & 44.73 & 49.77 & 30.33 & 46.04 & 47.48 & 49.94 & 0.030 \\
\hline Men aged 51-69 & 33.85 & 47.93 & 51.37 & 50.81 & 36.27 & 48.33 & 54.15 & 50.32 & 0.030 \\
\hline Women aged 70 over & 6.61 & 25.05 & 4.30 & 20.30 & 7.38 & 26.19 & 8.04 & 27.99 & $0.040^{* * *}$ \\
\hline Men aged 70 over & 4.56 & 20.86 & 3.32 & 17.93 & 5.09 & 21.98 & 4.77 & 21.38 & 0.010 \\
\hline
\end{tabular}

Source: The following data sources, if not specifically stated, are from CHIP Notes: (.): Standard error; significant at the $1 \%\left({ }^{* * *}\right), 5 \%\left({ }^{* *}\right)$ and $10 \%\left({ }^{*}\right)$ level respectively 
Table 3 Summary statistics. Men

\begin{tabular}{|c|c|c|c|c|c|c|c|c|c|}
\hline & \multicolumn{4}{|c|}{ Control } & \multicolumn{4}{|c|}{ Treatment } & \multirow{3}{*}{$\begin{array}{l}\begin{array}{l}\text { Difference-in- } \\
\text { differences }\end{array} \\
\text { Land security } \times \text { policy }\end{array}$} \\
\hline & \multicolumn{2}{|c|}{ Pre-reform } & \multicolumn{2}{|c|}{ Post-reform } & \multicolumn{2}{|c|}{ Pre-reform } & \multicolumn{2}{|c|}{ Post-reform } & \\
\hline & Mean & S.D. & Mean & S.D. & Mean & S.D. & Mean & S.D. & \\
\hline Observations & 12,854 & & 586 & & 10,146 & & 7994 & & 31,580 \\
\hline Age & 36.16 & 13.53 & 41.51 & 13.30 & 36.52 & 13.62 & 41.26 & 13.36 & 0.090 \\
\hline Education level & 7.19 & 2.75 & 7.87 & 2.38 & 7.47 & 2.64 & 7.91 & 2.25 & 0.080 \\
\hline Marry status & 0.90 & 0.35 & 0.80 & 0.43 & 0.83 & 0.41 & 0.81 & 0.43 & 0.020 \\
\hline Log land & 1.94 & 0.76 & 1.09 & 1.28 & 1.80 & 0.75 & 1.29 & 0.93 & $0.440^{* * *}$ \\
\hline Log asset & 7.49 & 1.28 & 8.01 & 1.42 & 7.57 & 1.26 & 8.14 & 1.36 & $0.320^{* * *}$ \\
\hline Log per capita income & 8.02 & 0.53 & 8.77 & 0.40 & 8.00 & 0.59 & 8.56 & 0.51 & $-0.100^{* * *}$ \\
\hline Log consumption_level & 8.03 & 0.04 & 8.56 & 0.04 & 8.00 & 0.03 & 8.56 & 0.04 & -0.003 \\
\hline Girls aged 6 or younger & 11.37 & 34.49 & 9.56 & 30.56 & 11.20 & 33.50 & 11.30 & 33.87 & 0.020 \\
\hline Boys aged 6 or younger & 13.72 & 37.06 & 8.36 & 27.71 & 13.14 & 35.41 & 13.57 & 36.51 & $0.050^{* * *}$ \\
\hline Boys aged 7-14 & 28.10 & 54.04 & 13.48 & 35.65 & 25.17 & 49.95 & 16.07 & 40.71 & 0.030 \\
\hline Girls aged 7-14 & 25.36 & 52.04 & 12.12 & 34.69 & 21.46 & 47.20 & 13.51 & 38.29 & 0.010 \\
\hline Women aged 15-25 & 53.86 & 72.79 & 37.37 & 60.93 & 51.36 & 70.45 & 41.21 & 64.05 & 0.040 \\
\hline Men aged 15-25 & 77.37 & 78.78 & 55.63 & 69.75 & 77.20 & 81.51 & 55.50 & 71.10 & 0.000 \\
\hline Women aged 26-39 & 36.44 & 49.17 & 34.81 & 49.09 & 38.25 & 50.22 & 39.29 & 54.02 & $0.040^{* *}$ \\
\hline Men aged 26-39 & 41.29 & 54.52 & 50.34 & 60.27 & 43.05 & 55.82 & 53.47 & 64.36 & 0.030 \\
\hline Women aged 40-50 & 45.94 & 49.95 & 43.34 & 51.62 & 45.96 & 49.84 & 41.01 & 49.19 & 0.020 \\
\hline Men aged 40-50 & 43.39 & 50.02 & 36.18 & 48.80 & 44.38 & 49.98 & 35.55 & 48.16 & 0.010 \\
\hline Women aged 51-69 & 27.95 & 45.19 & 46.08 & 49.89 & 30.02 & 45.90 & 49.20 & 50.00 & 0.030 \\
\hline Men aged 51-69 & 37.19 & 49.16 & 55.29 & 50.78 & 38.40 & 49.04 & 59.21 & 50.13 & $0.040^{*}$ \\
\hline Women aged 70 over & 6.84 & 25.36 & 5.97 & 25.79 & 7.46 & 26.31 & 8.36 & 28.48 & $0.020^{* *}$ \\
\hline Men aged 70 over & 4.54 & 20.81 & 3.58 & 18.60 & 4.97 & 21.73 & 4.97 & 21.78 & 0.010 \\
\hline
\end{tabular}

Source: The following data sources, if not specifically stated, are from CHIP

Notes: (.): Standard error; significant at the $1 \%\left({ }^{* *}\right), 5 \%\left({ }^{* *}\right)$ and $10 \%\left({ }^{*}\right)$ level respectively

significant changes in the average characteristics of the two groups. This evidence suggests that, at least in terms of observed characteristics, the main results discussed below are not influenced by compositional effects.

\section{Application and results}

\subsection{Descriptive analysis}

Table 4 presents the off-farm employment for men and women from 1995 to 2008. This table shows that off-farm employment rates increased largely for both men and women, and this increase is mainly from wage employment as self-employment increased slowly.

Table 4 Summary statistics of labor market outcomes

\begin{tabular}{|c|c|c|c|c|c|c|c|c|c|c|}
\hline \multirow[t]{2}{*}{ Year } & \multicolumn{2}{|c|}{ Employment (\%) } & \multicolumn{2}{|l|}{ Farm (\%) } & \multicolumn{2}{|c|}{ Off-farm (\%) } & \multicolumn{2}{|c|}{ Wage employment (\%) } & \multicolumn{2}{|c|}{ Self-employment (\%) } \\
\hline & Women & Men & Women & Men & Women & Men & Women & Men & Women & Men \\
\hline 1995 & 87.78 & 87.99 & 78.01 & 70.19 & 9.77 & 17.80 & 8.38 & 14.58 & 1.39 & 3.22 \\
\hline 2002 & 88.43 & 98.34 & 70.99 & 51.16 & 17.44 & 38.18 & 14.84 & 32.86 & 2.60 & 5.33 \\
\hline 2008 & 90.95 & 94.48 & 56.08 & 39.10 & 34.86 & 55.37 & 31.91 & 49.51 & 2.95 & 5.86 \\
\hline
\end{tabular}

Source: The following data sources, if not specifically stated, are from CHIP 


\subsection{Baseline results}

The interaction between land rights security and the year of 2008 dummy captures the effect of being in a land security village on off-farm work after the RLCL was implemented, relative to those located in villages with land insecurity. Table 5 presents the baseline estimates of the effects of the RLCL on female and male labor market. Each column reports the OLS estimates of the regression equation for the main outcomes: employment, farm work, off-farm work, wage employment, and self-employment. The first row in Table 5 presents the estimates and standard errors of the interaction coefficient in equation, which captures the impact of the RLCL. The second row is the interaction between land rights security and the year of 1995 dummy variable, which indicates the treatment effect before the RLCL. The year 2002 is set as the reference year. The variables for years of 1995 and 2008 are pre-policy and post-policy, respectively. The third row displays the estimates of the coefficient of the treatment variable (land security in equation). The last row in the table reports the average of each column's dependent variable for the period before the implementation of the RLCL. The discussion focuses on the regression results with the full set of controls in regression equation, county fixed effects, individual age and education-level characteristics, land holding by household, asset used for agriculture by household, household demographic variables, and village characteristics, which are included but not reported. Since the percent of farmers who work in both activities is low (there are $6.6 \%$ women and $18 \%$ men who work both in farm and off-farm activities), we have restricted the analysis to the sample of individuals who engage in one employment only. ${ }^{7}$

The estimates in column 1 of Table 5 present the policy impact on the employment rate for men and women. The coefficient on interaction of the land rights security variable and year dummy of land security $\times$ year08 shows that both the employment rate of women (5.8 percentage points) and men (4.1 percentage points) increased and both are statistically significant at the one percent level, respectively. In terms of the pre-policy average, the effect represents an increase of $6.6 \%$ for women and $4.6 \%$ for men. The variable of land security $\times$ year 95 (which captures pre-trend effects) is not statistically significant for women at the usual statistical levels. In contrast, the estimate for men shows the coefficient on this variable is statistically significant at the $10 \%$ statistical level, suggesting some caution for interpretation. For the rest of the estimates presented in Table 5, we cannot reject the null of the coefficient on land security $\times$ year 95 that is statistically different of zero.

The estimates in column 2 of Table 5 are the policy effect on farm employment for men and women. It shows that the coefficient of land security $\times$ year08 is negative for both women and men and statistically significant at the $5 \%$ level for men. The estimates in column 3 correspond to the main outcome of interest, that is, off-farm employment. The results indicate a statistically significant increase in those villages with land security after the RLCL relative to those villages without land security. For off-farm work, there is an increase of $7.1 \%$ points for women, and an increase of $10 \%$ points for men, both of them are significant at the $1 \%$ level. In terms of the pre-policy average, the effect represents an increase of $39.4 \%$ for women and $29.4 \%$ for men. Similarly, the variable of land security $\times$ year 95 is not statistically significant in the estimations. As the employment has increased significantly for both women and men, we can conclude that 


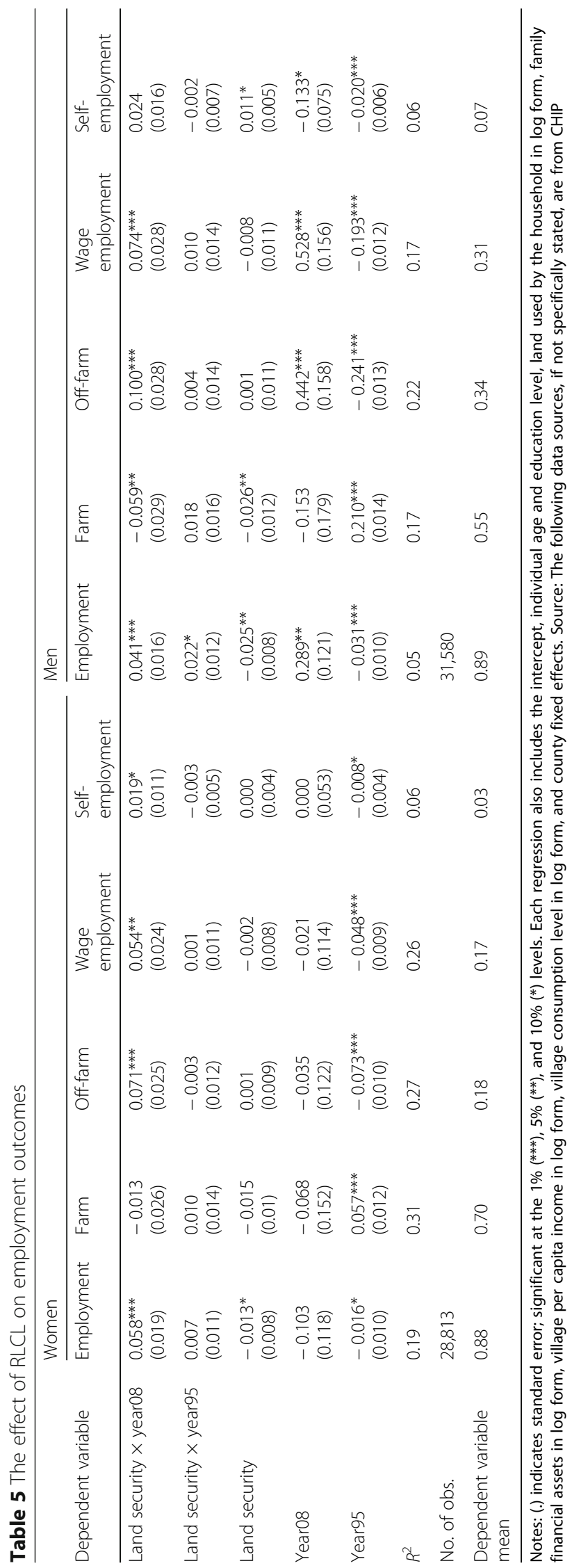


the policy effect on off-farm employment seems to be driven by an employment effect for women. For men, the employment on farm decreased significantly. Therefore, the policy effect on off-farm seems to be both a switching effect from farm activities to offfarm and an employment effect.

We then separate the off-farm work to wage employment and self-employment. Columns 4 to 5 reveal that the overall effect on off-farm work was due to an increase in wage employment, which is consistent with the discussion in Section 3. For being employed as wage workers, there is an increase of 5.4 percentage points for women (significant at the 5\% level) and an increase of 7.4 percentage points for men (significant at the $1 \%$ level). In terms of the pre-policy average, this implies that the effect is representative of an increase of $31.8 \%$ for women and $23.9 \%$ for men.

With respect to the participation of self-employment, Table 5 shows that the sign of the interaction between land rights security and the year of 2008 are both small in magnitude. It is statistically significant at the $10 \%$ level for women and not statistically significant for men. Overall, the pattern of results in Table 5 indicates that women's labor market behavior responded to the policy reform as predicted in Section 3. The RLCL is associated with an increase in off-farm employment rates, and the overall effect on off-farm work was due to an increase in wage employment.

In addition, the dependent variables were estimated at the village level (see Table 12 in the Appendix section). The result is consistent with the conclusions mentioned above. At the same time, the probit estimates of the effect of the RLCL on female and male labor market are shown in Tables 13 and 14 in the Appendix section. The main results are qualitatively similar to the regressions which are estimated by the OLS. For simplicity in the interpretation of the coefficients, we decided to report the coefficients as estimated by the OLS.

\subsection{Heterogeneous effects}

Exploring for heterogeneity effects across individuals and households is likely to be important in satisfactorily explaining their off-farm activities. Households and individuals differ considerably in terms of their on-farm productivities and their ability to access these off-farm opportunities. Heterogeneity in household labor or land endowments and human capital also induces labor re-allocation from farm to off-farm activities.

We examine which groups of individuals are particularly affected by land tenure security (full results are not shown here for lack of space but available upon request to the authors). First, we stratify the sample into two groups based on age. The results reveal that the impact on off-farm work and wage employment is significant and larger for men and women older than 26. Second, when stratification is carried out by educational attainment, we find strong evidence that the less educated are affected. We also find a stronger effect of land tenure security on the labor market behavior of older people and of those with a low level of education. The result is consistent with the evidence of $\mathrm{Mu}$ and Giles (2014) on the labor supply responses to land security rights. Third, we stratify the sample by wage employment and self-employment in their local county and outside of their hometown. There are 4.2 percentage points for women and 7 percentage points for men, participating in the local wage labor market. With respect to self-employment, there is a significant increase in local self-employment for men, but the effect is not statistically significant for women (Tables 6, 7, 8, and 9). 
Table 6 The effect of RLCL on employment outcomes by age. Women

\begin{tabular}{|c|c|c|c|c|c|c|}
\hline \multirow{2}{*}{$\begin{array}{l}\text { Group } \\
\text { Dependent variable }\end{array}$} & \multicolumn{3}{|c|}{ Age 16-25 } & \multicolumn{3}{|c|}{ Age 26 and older } \\
\hline & Off-farm & $\begin{array}{l}\text { Wage } \\
\text { employment }\end{array}$ & $\begin{array}{l}\text { Self- } \\
\text { employment }\end{array}$ & Off-farm & $\begin{array}{l}\text { Wage } \\
\text { employment }\end{array}$ & $\begin{array}{l}\text { Self- } \\
\text { employment }\end{array}$ \\
\hline $\begin{array}{l}\text { Land security } \times \\
\text { year08 }\end{array}$ & $\begin{array}{l}0.014 \\
(0.069)\end{array}$ & $\begin{array}{l}0.006 \\
(0.069)\end{array}$ & $\begin{array}{l}0.008 \\
(0.010)\end{array}$ & $\begin{array}{l}0.072^{* * *} \\
(0.025)\end{array}$ & $\begin{array}{l}0.051^{* *} \\
(0.024)\end{array}$ & $\begin{array}{l}0.024^{*} \\
(0.013)\end{array}$ \\
\hline $\begin{array}{l}\text { Land security } \times \\
\text { year95 }\end{array}$ & $\begin{array}{l}0.029 \\
(0.028)\end{array}$ & $\begin{array}{l}0.029 \\
(0.027)\end{array}$ & $\begin{array}{l}0.004 \\
(0.009)\end{array}$ & $\begin{array}{l}-0.015 \\
(0.011)\end{array}$ & $\begin{array}{l}-0.010 \\
(0.010)\end{array}$ & $\begin{array}{l}-0.006 \\
(0.006)\end{array}$ \\
\hline Land security & $\begin{array}{l}0.014 \\
(0.021)\end{array}$ & $\begin{array}{l}-0.015 \\
(0.021)\end{array}$ & $\begin{array}{l}-0.001 \\
(0.007)\end{array}$ & $\begin{array}{l}0.010 \\
(0.009)\end{array}$ & $\begin{array}{l}0.006 \\
(0.008)\end{array}$ & $\begin{array}{l}0.001 \\
(0.005)\end{array}$ \\
\hline Year08 & $\begin{array}{l}0.212 \\
(0.298)\end{array}$ & $\begin{array}{l}0.207 \\
(0.295)\end{array}$ & $\begin{array}{l}0.041 \\
(0.070)\end{array}$ & $\begin{array}{l}-0.021 \\
(0.119)\end{array}$ & $\begin{array}{l}-0.002 \\
(0.104)\end{array}$ & $\begin{array}{l}-0.016 \\
(0.069)\end{array}$ \\
\hline Year95 & $\begin{array}{l}-0.040 \\
(0.026)\end{array}$ & $\begin{array}{l}-0.022 \\
(0.026)\end{array}$ & $\begin{array}{l}0.001 \\
(0.008)\end{array}$ & $\begin{array}{l}-0.064^{* * *} \\
(0.009)\end{array}$ & $\begin{array}{l}-0.039^{* * *} \\
(0.008)\end{array}$ & $\begin{array}{l}-0.009^{*} \\
(0.005)\end{array}$ \\
\hline$R^{2}$ & 0.31 & 0.30 & 0.06 & 0.28 & 0.26 & 0.07 \\
\hline No. of obs. & 7763 & & & 21,050 & & \\
\hline $\begin{array}{l}\text { Dependent variable } \\
\text { mean }\end{array}$ & 0.30 & 0.29 & 0.03 & 0.14 & 0.12 & 0.04 \\
\hline
\end{tabular}

Notes: (.) indicates standard error; significant at the $1 \%\left({ }^{* *}\right), 5 \%(* *)$, and $10 \%\left({ }^{*}\right)$ levels. Each regression also includes the intercept, individual age and education level, land used by the household in log form, family financial assets in log form, village per capita income in log form, village consumption level in log form, and county fixed effects. Source: The following data sources, if not specifically stated, are from CHIP

\subsection{Robustness}

The following section present the robustness tests on the difference-in-differences estimates presented in the previous section. These exercises are based on the model of equation, with full controls for individual characteristics, household characteristics, and county-fixed effects, as in the previous analysis. The estimates on the previous regression analysis show that the coefficient on the interaction between land rights security and the year of 1995 dummy variable is insignificant statistically for (almost) all of the

Table 7 The effect of RLCL on employment outcomes by age. Men

\begin{tabular}{|c|c|c|c|c|c|c|}
\hline \multirow{2}{*}{$\begin{array}{l}\text { Group } \\
\text { Dependent variable }\end{array}$} & \multicolumn{3}{|l|}{ Age 16-25 } & \multicolumn{3}{|c|}{ Age 26 and older } \\
\hline & Off-farm & $\begin{array}{l}\text { Wage } \\
\text { employment }\end{array}$ & $\begin{array}{l}\text { Self- } \\
\text { employment }\end{array}$ & Off-farm & $\begin{array}{l}\text { Wage } \\
\text { employment }\end{array}$ & $\begin{array}{l}\text { Self- } \\
\text { employment }\end{array}$ \\
\hline $\begin{array}{l}\text { Land security } \times \\
\text { year08 }\end{array}$ & $\begin{array}{l}0.042 \\
(0.064)\end{array}$ & $\begin{array}{l}0.065 \\
(0.067)\end{array}$ & $\begin{array}{l}-0.021 \\
(0.022)\end{array}$ & $\begin{array}{l}0.100^{*} \\
(0.029)\end{array}$ & $\begin{array}{l}0.066^{* *} \\
(0.029)\end{array}$ & $\begin{array}{l}0.030^{*} \\
(0.018)\end{array}$ \\
\hline $\begin{array}{l}\text { Land security } \times \\
\text { year95 }\end{array}$ & $\begin{array}{l}-0.006 \\
(0.027)\end{array}$ & $\begin{array}{l}0.004 \\
(0.027)\end{array}$ & $\begin{array}{l}0.008 \\
(0.011)\end{array}$ & $\begin{array}{l}0.011 \\
(0.016)\end{array}$ & $\begin{array}{l}0.012 \\
(0.016)\end{array}$ & $\begin{array}{l}0.002 \\
(0.008)\end{array}$ \\
\hline Land security & $\begin{array}{l}-0.003 \\
(0.021)\end{array}$ & $\begin{array}{l}-0.015 \\
(0.020)\end{array}$ & $\begin{array}{l}0.009 \\
(0.008)\end{array}$ & $\begin{array}{l}-0.001 \\
(0.013)\end{array}$ & $\begin{array}{l}-0.005 \\
(0.013)\end{array}$ & $\begin{array}{l}0.006 \\
(0.007)\end{array}$ \\
\hline Year08 & $\begin{array}{l}0.202 \\
(0.298)\end{array}$ & $\begin{array}{l}0.279 \\
(0.295)\end{array}$ & $\begin{array}{l}0.027 \\
(0.093)\end{array}$ & $\begin{array}{l}0.650^{* * *} \\
(0.179)\end{array}$ & $\begin{array}{l}0.671^{* * *} \\
(0.178)\end{array}$ & $\begin{array}{l}-0.115 \\
(0.096)\end{array}$ \\
\hline Year95 & $\begin{array}{l}-0.216^{* * *} \\
(0.029)\end{array}$ & $\begin{array}{l}-0.194^{* * *} \\
(0.029)\end{array}$ & $\begin{array}{l}0.014 \\
(0.011)\end{array}$ & $\begin{array}{l}-0.269^{* * *} \\
(0.015)\end{array}$ & $\begin{array}{l}-0.211^{* * *} \\
(0.014)\end{array}$ & $\begin{array}{l}-0.031^{* * *} \\
(0.007)\end{array}$ \\
\hline$R^{2}$ & 0.32 & 0.31 & 0.09 & 0.30 & 0.24 & 0.11 \\
\hline No. of obs. & 8195 & & & 23,385 & & \\
\hline $\begin{array}{l}\text { Dependent variable } \\
\text { mean }\end{array}$ & 0.33 & 0.32 & 0.04 & 0.35 & 0.31 & 0.08 \\
\hline
\end{tabular}

Notes: (.) indicates standard error; significant at the $1 \%\left({ }^{* *}\right), 5 \%\left({ }^{* *}\right)$, and $10 \%\left({ }^{*}\right)$ levels. Each regression also includes the intercept, individual age and education level, land used by the household in log form, family financial assets in log form, village per capita income in log form, village consumption level in log form, and county fixed effects. Source: The following data sources, if not specifically stated, are from CHIP 
Table 8 The effect of RLCL on employment outcomes by education level. Women

\begin{tabular}{|c|c|c|c|c|c|c|}
\hline \multirow{2}{*}{$\begin{array}{l}\text { Group } \\
\text { Dependent variable }\end{array}$} & \multicolumn{3}{|c|}{ Years of schooling: $\leq 9$} & \multicolumn{3}{|c|}{ Years of schooling: 10 or more } \\
\hline & Off-farm & $\begin{array}{l}\text { Wage } \\
\text { employment }\end{array}$ & $\begin{array}{l}\text { Self- } \\
\text { employment }\end{array}$ & Off-farm & $\begin{array}{l}\text { Wage } \\
\text { employment }\end{array}$ & $\begin{array}{l}\text { Self- } \\
\text { employment }\end{array}$ \\
\hline $\begin{array}{l}\text { Land security } \times \\
\text { year08 }\end{array}$ & $\begin{array}{l}0.070^{* * *} \\
(0.025)\end{array}$ & $\begin{array}{l}0.054^{* *} \\
(0.024)\end{array}$ & $\begin{array}{l}0.017 \\
(0.011)\end{array}$ & $\begin{array}{l}0.104 \\
(0.092)\end{array}$ & $\begin{array}{l}0.074 \\
(0.091)\end{array}$ & $\begin{array}{l}0.035 \\
(0.032)\end{array}$ \\
\hline $\begin{array}{l}\text { Land security } \times \\
\text { year95 }\end{array}$ & $\begin{array}{l}-0.007 \\
(0.012)\end{array}$ & $\begin{array}{l}-0.003 \\
(0.011)\end{array}$ & $\begin{array}{l}-0.001 \\
(0.005)\end{array}$ & $\begin{array}{l}0.058 \\
(0.057)\end{array}$ & $\begin{array}{l}0.061 \\
(0.057)\end{array}$ & $\begin{array}{l}-0.031^{*} \\
(0.016)\end{array}$ \\
\hline Land security & $\begin{array}{l}0.005 \\
(0.009)\end{array}$ & $\begin{array}{l}0.002 \\
(0.009)\end{array}$ & $\begin{array}{l}0.000 \\
(0.004)\end{array}$ & $\begin{array}{l}-0.025 \\
(0.036)\end{array}$ & $\begin{array}{l}-0.028 \\
(0.035)\end{array}$ & $\begin{array}{l}-0.004 \\
(0.014)\end{array}$ \\
\hline Year08 & $\begin{array}{l}-0.094 \\
(0.123)\end{array}$ & $\begin{array}{l}-0.078 \\
(0.115)\end{array}$ & $\begin{array}{l}0.006 \\
(0.054)\end{array}$ & $\begin{array}{l}0.901 \\
(0.663)\end{array}$ & $\begin{array}{l}0.967 \\
(0.658)\end{array}$ & $\begin{array}{l}-0.25 \\
(0.314)\end{array}$ \\
\hline Year95 & $\begin{array}{l}-0.081^{* * *} \\
(0.010)\end{array}$ & $\begin{array}{l}-0.057^{* * *} \\
(0.009)\end{array}$ & $\begin{array}{l}-0.008^{*} \\
(0.004)\end{array}$ & $\begin{array}{l}-0.026 \\
(0.053)\end{array}$ & $\begin{array}{l}0.032 \\
(0.052)\end{array}$ & $\begin{array}{l}-0.016 \\
(0.023)\end{array}$ \\
\hline$R^{2}$ & 0.27 & 0.26 & 0.06 & 0.33 & 0.32 & 0.17 \\
\hline No. of obs. & 26,329 & & & 2484 & & \\
\hline $\begin{array}{l}\text { Dependent variable } \\
\text { mean }\end{array}$ & 0.17 & 0.15 & 0.03 & 0.32 & 0.30 & 0.05 \\
\hline
\end{tabular}

Notes: (.) indicates standard error; significant at the $1 \%\left({ }^{* * *}\right), 5 \%\left({ }^{* *}\right)$, and $10 \%\left({ }^{*}\right)$ levels. Each regression also includes the intercept, individual age and education level, land used by the household in log form, family financial assets in log form, village per capita income in log form, village consumption level in log form, and county fixed effects. Source: The following data sources, if not specifically stated, are from CHIP

estimated models. This reflects that possible trends which affect treatment and control groups differently are not present in the setting, i.e., there is no significant evidence that we can reject the parallel trends before the policy reform assumption.

A further concern for the identification strategy is that the treatment and comparison groups may have changed over the period under study, confounding treatment with composition effects. The summary statistics and the unconditional difference-in-differences estimates in Tables 2 and 3 indicate that the main

Table 9 The effect of RLCL on employment outcomes by education level. Men

\begin{tabular}{|c|c|c|c|c|c|c|}
\hline \multirow{2}{*}{$\begin{array}{l}\text { Group } \\
\text { Dependent variable }\end{array}$} & \multicolumn{3}{|c|}{ Years of schooling: $\leq 9$} & \multicolumn{3}{|c|}{ Years of schooling: 10 or more } \\
\hline & Off-farm & $\begin{array}{l}\text { Wage } \\
\text { employment }\end{array}$ & $\begin{array}{l}\text { Self- } \\
\text { employment }\end{array}$ & Off-farm & $\begin{array}{l}\text { Wage } \\
\text { employment }\end{array}$ & $\begin{array}{l}\text { Self- } \\
\text { employment }\end{array}$ \\
\hline $\begin{array}{l}\text { Land security } \times \\
\text { year08 }\end{array}$ & $\begin{array}{l}0.097^{* * *} \\
(0.030)\end{array}$ & $\begin{array}{l}0.077^{* *} \\
(0.030)\end{array}$ & $\begin{array}{l}0.019 \\
(0.017)\end{array}$ & $\begin{array}{l}0.016 \\
(0.062)\end{array}$ & $\begin{array}{l}0.016 \\
(0.062)\end{array}$ & $\begin{array}{l}-0.013 \\
(0.032)\end{array}$ \\
\hline $\begin{array}{l}\text { Land security } \times \\
\text { year95 }\end{array}$ & $\begin{array}{l}-0.009 \\
(0.015)\end{array}$ & $\begin{array}{l}-0.004 \\
(0.015)\end{array}$ & $\begin{array}{l}0.004 \\
(0.007)\end{array}$ & $\begin{array}{l}0.067 \\
(0.042)\end{array}$ & $\begin{array}{l}0.067 \\
(0.042)\end{array}$ & $\begin{array}{l}-0.021 \\
(0.019)\end{array}$ \\
\hline Land security & $\begin{array}{l}0.008 \\
(0.012)\end{array}$ & $\begin{array}{l}0.002 \\
(0.012)\end{array}$ & $\begin{array}{l}0.004 \\
(0.006)\end{array}$ & $\begin{array}{l}-0.052 \\
(0.028)\end{array}$ & $\begin{array}{l}-0.052^{*} \\
(0.028)\end{array}$ & $\begin{array}{l}0.024^{*} \\
(0.014)\end{array}$ \\
\hline Year08 & $\begin{array}{l}0.378^{* *} \\
(0.166)\end{array}$ & $\begin{array}{l}0.426^{* * *} \\
(0.163)\end{array}$ & $\begin{array}{l}-0.044 \\
(0.081)\end{array}$ & $\begin{array}{l}0.644 \\
(0.529)\end{array}$ & $\begin{array}{l}0.514 \\
(0.527)\end{array}$ & $\begin{array}{l}-0.223 \\
(0.241)\end{array}$ \\
\hline Year95 & $\begin{array}{l}-0.258^{* * *} \\
(0.013)\end{array}$ & $\begin{array}{l}-0.207^{* * *} \\
(0.013)\end{array}$ & $\begin{array}{l}-0.021^{* * *} \\
(0.006)\end{array}$ & $\begin{array}{l}-0.205^{* * *} \\
(0.041)\end{array}$ & $\begin{array}{l}-0.151^{* * *} \\
(0.041)\end{array}$ & $\begin{array}{l}-0.026 \\
(0.016)\end{array}$ \\
\hline$R^{2}$ & 0.29 & 0.24 & 0.10 & 0.29 & 0.25 & 0.12 \\
\hline No. of obs. & 26,607 & & & 4973 & & \\
\hline $\begin{array}{l}\text { Dependent variable } \\
\text { mean }\end{array}$ & 0.33 & 0.29 & 0.06 & 0.42 & 0.38 & 0.07 \\
\hline
\end{tabular}

Notes: (.) indicates standard error; significant at the $1 \%\left({ }^{* * *}\right), 5 \%\left({ }^{* *}\right)$, and $10 \%\left({ }^{*}\right)$ levels. Each regression also includes the intercept, individual age and education level, land used by the household in log form, family financial assets in log form, village per capita income in log form, village consumption level in log form, and county fixed effects. Source: The following data sources, if not specifically stated, are from CHIP 
individual characteristics of both groups did not change substantially before and after the policy change, but the household characteristics of both groups changed a lot. We include the interaction terms between the land security indicator and the full set of control covariates in the regression. Results in Table 10 indicate that the main estimates are also robust for this alternative. The estimated coefficients for the main outcomes are somewhat smaller than the baseline results in Table 5, but they remain significant at the usual confidence levels.

In general, the robustness tests suggest that changes in the composition of the treatment and comparison groups did not introduce a spurious correlation between changes in the outcomes before and after the reform.

Finally, an additional concern is related to the form in which we computed the standard errors of estimated regression. In particular, as the dependent variable in regression models varies across individuals within villages, a certain degree of correlation between the outcomes of individuals belonging to the same village could be expected and thus affect the coefficient standard errors. In order to check the extent to which this issue could affect the inference in our setting, Tables 17 and 18 in the Appendix section replicate our main results in Table 5 by clustering standard errors at village level. As can be seen in those tables, the results remain basically unchanged.

Additionally, we estimate the main results by restricting the data of CHIP 1995 and 2002 to the nine provinces of CHIP 2008. We found the results of both estimates are qualitatively the same (full results are not shown for lack of space but available upon request to the authors).

\section{Conclusions}

In the paper, we investigate the effect of land rights security on labor market behavior. Until the early 2000s, farmers in rural China faced a substantial level of risk of losing land in village land reallocations. In 2002, China passed the Rural Land Contracting Law, which aims to secure the land rights of farmers. How does the RLCL affect farmers' labor market behavior? Based upon the difference-indifferences analysis, we found that land rights security has a positive influence on both women's and men's labor market behavior. In terms of the pre-policy average, employment increases $6.6 \%$ for women and $4.6 \%$ for men, and off-farm employment increases $39.4 \%$ for women and $29.4 \%$ for men. We separate the off-farm work to wage employment and self-employment. It reveals that the overall effect on off-farm work was due to an increase in wage employment, as there is an increase of $31.8 \%$ for women and $23.9 \%$ for men in wage employment with respect to the pre-reform average.

The lesson from this paper is that off-farm employment, especially wage employment, is shown to be highly correlated with the RLCL. Because of these relationships, it seems that the government should continue its policies to insure farmers' land security rights and encourage land rental. The finding has important policy implications: with the expansion of land rental markets, we should expect to see an expansion in China's offfarm employment and a decline in the rural-urban income gap due to more wage income earned by farmers. The increased employment rate for women have positive 


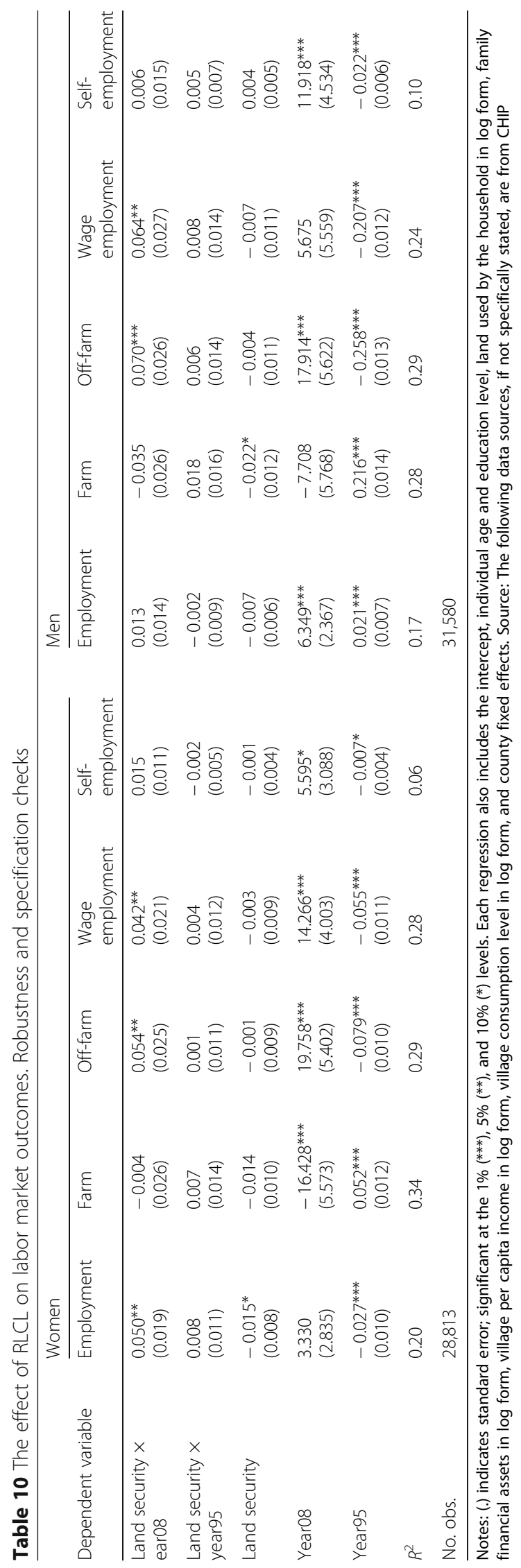


implications for the well-being of women, which may increase women's economic empowerment and ability to influence the intra household.

Nonetheless, the conclusions from the present study require some qualification. First, considering the time variation was used in the study for identification, the RLCL was probably also accompanied by many other policy changes, that are also likely to have affected labor market decisions. We cannot disentangle the potential relative effects in the setting. Second, the period in which the RLCL was approved in China coincided with a historic economic boom, making it difficult to determine the extent to which the changes in labor market behavior due to the economic upturn could have affected our results. This caveat might be exacerbated by the unavailability of additional years of (CHIP) data to better control for possible confounding factors. Despite these limitations, the robustness results and the virtual non-existence of pre-trends on labor market outcomes (even with the small number of pre-reform data considered) allow us to be confident about the results. Finally, it is important to consider that estimates of the impact of the RLCL on labor market outcomes in our study is not based on any data in which land security was literally absent. The identification strategy is based on the level of land security across villages' time, so the estimated coefficient of impact cannot be interpreted as treatment on the treated parameters.

\section{Endnotes}

${ }^{1}$ For instance, the Land Management Law passed in 1998 restricted land adjustments by requiring the agreement of two thirds of the village members.

${ }^{2}$ Some research examined women's land rights in the Household Responsibility System in rural China (Duncan and Li 2001; Li and Xi 2006; Liaw 2008). Under the HRS, women's land rights can be more easily challenged and jeopardized than men's. Women lost land rights after marriage, and they often had to wait for the next reallocation to be assigned with land.

${ }^{3}$ Despite the institutional changes under the HRS, land was not privatized and ownership remained "collective"; in particular, the village authorities in the actual management strongly influenced the land use and allocation by households (Rozelle et al. 2002).

${ }^{4}$ Actually, the trends of self-employment and migrant wage earners of the non-farm rural employment grew in parallel during the 1980s and 1990s. However, the number of wage workers among migrants in 2008 was higher than self-employed workers (Wang et al. 2011).

${ }^{5}$ The CHIP conducted five waves of household surveys, in 1988, 1995, 2002, 2007 and lastly 2008, but only the waves in 1995, 2002 and 2008 have land information.

${ }^{6}$ The variables of income per capita and the balance of family financial assets are discounted by the consumer price index at the provincial level with 1995 as the base year. The price index is obtained from China Statistical Yearbooks of various years.

${ }^{7}$ If a person who works both in farm and off farm activities, his/her main activity was defined according to the working time spent on each of them (i.e., if his/her farm working time is more than off farm time, he/she was classified as the farm activity). 


\section{Appendix}

Table 11 Statistical description of variables

\begin{tabular}{|c|c|c|c|c|}
\hline \multirow[b]{2}{*}{ Variable } & \multicolumn{2}{|l|}{ Female } & \multicolumn{2}{|l|}{ Male } \\
\hline & Mean & Std. Dev. & Mean & Std. Dev. \\
\hline Off-farm employment participation rate & 0.190 & 0.392 & 0.355 & 0.479 \\
\hline Wage employment participation rate & 0.168 & 0.373 & 0.308 & 0.462 \\
\hline Self-employment participation rate & 0.022 & 0.148 & 0.047 & 0.212 \\
\hline The proportion of engaged in farming & 0.698 & 0.459 & 0.547 & 0.498 \\
\hline Employment participation rate & 0.883 & 0.321 & 0.891 & 0.312 \\
\hline Land security $\times$ year 08 & 0.239 & 0.426 & 0.253 & 0.435 \\
\hline Land security $\times$ year 95 & 0.124 & 0.33 & 0.116 & 0.32 \\
\hline Land security & 0.561 & 0.496 & 0.574 & 0.494 \\
\hline Year08 & 0.256 & 0.437 & 0.272 & 0.445 \\
\hline Year95 & 0.381 & 0.486 & 0.358 & 0.48 \\
\hline Age & 36.773 & 13.096 & 37.666 & 13.689 \\
\hline Age squared & 1523.733 & 1000.176 & 1606.098 & 1068.355 \\
\hline Education & 6.160 & 3.070 & 7.478 & 2.604 \\
\hline Married & 0.887 & 0.365 & 0.855 & 0.398 \\
\hline Ln land & 1.720 & 0.857 & 1.712 & 0.861 \\
\hline Ln asset & 8.210 & 1.287 & 8.21 & 1.286 \\
\hline Number of girls aged 6 or younger & 0.117 & 0.345 & 0.113 & 0.339 \\
\hline Number of boys aged 6 or younger & 0.142 & 0.370 & 0.134 & 0.362 \\
\hline Number of boys aged 7-14 & 0.276 & 0.519 & 0.238 & 0.496 \\
\hline Number of girls aged 7-14 & 0.225 & 0.491 & 0.209 & 0.473 \\
\hline Number of women aged 15-25 & 0.734 & 0.839 & 0.495 & 0.699 \\
\hline Number of men aged 15-25 & 0.531 & 0.678 & 0.714 & 0.783 \\
\hline Number of women aged 26-39 & 0.411 & 0.521 & 0.377 & 0.508 \\
\hline Number of men aged 26-39 & 0.417 & 0.547 & 0.451 & 0.579 \\
\hline Number of women aged 40-50 & 0.462 & 0.500 & 0.446 & 0.498 \\
\hline Number of men aged $40-50$ & 0.422 & 0.496 & 0.416 & 0.497 \\
\hline Number of women aged 51-69 & 0.339 & 0.475 & 0.343 & 0.476 \\
\hline Number of men aged 51-69 & 0.398 & 0.494 & 0.435 & 0.503 \\
\hline Number of women aged 70 over & 0.072 & 0.261 & 0.074 & 0.265 \\
\hline Number of men aged 70 over & 0.048 & 0.213 & 0.048 & 0.213 \\
\hline Ln per capita income & 8.164 & 0.602 & 8.164 & 0.599 \\
\hline Log consumption level & 8.157 & 0.238 & 8.165 & 0.243 \\
\hline No. of obs. & 28,813 & & 31,580 & \\
\hline
\end{tabular}

Source: The following data sources, if not specifically stated, are from CHIP 
Table 12 The effect of RLCL on employment outcomes. Estimates by clustering data at village's level

\begin{tabular}{llllll}
\hline Dependent variable & Employment & Farm & Off-farm & $\begin{array}{l}\text { Wage } \\
\text { employment }\end{array}$ & $\begin{array}{l}\text { Self- } \\
\text { employment }\end{array}$ \\
\hline Land security $\times$ & 0.017 & -0.058 & $0.075^{* *}$ & $0.098^{* * *}$ & -0.020 \\
year08 & $(0.02)$ & $(0.037)$ & $(0.035)$ & $(0.034)$ & $(0.027)$ \\
Land security $\times$ & -0.006 & -0.024 & 0.018 & 0.009 & $0.014^{*}$ \\
year95 & $(0.011)$ & $(0.019)$ & $(0.017)$ & $(0.015)$ & $(0.008)$ \\
Land security & -0.002 & -0.005 & 0.003 & 0.013 & -0.009 \\
& $(0.007)$ & $(0.013)$ & $(0.012)$ & $(0.011)$ & $(0.006)$ \\
Year08 & -0.025 & $-0.336^{*}$ & $0.311^{*}$ & $0.454^{* * *}$ & -0.006 \\
Year95 & $(0.111)$ & $(0.186)$ & $(0.161)$ & $(0.147)$ & $(0.086)$ \\
$R^{2}$ & $-0.032^{* * *}$ & $0.147^{* * *}$ & $-0.179^{* * *}$ & $-0.120^{* * *}$ & $-0.030^{* * *}$ \\
No. of obs. & $(0.008)$ & $(0.015)$ & $(0.013)$ & $(0.011)$ & $(0.007)$ \\
\hline
\end{tabular}

Notes: (.) indicates standard error; significant at the $1 \%\left({ }^{* * *}\right), 5 \%\left(^{(*}\right)$, and $10 \%\left(^{*}\right)$ levels. Source: The following data sources, if not specifically stated, are from CHIP

Table 13 The effect of RLCL on employment outcomes of women. Estimates by using a probit model

\begin{tabular}{llllll}
\hline Dependent variable & Employment & Farm & Off-farm & $\begin{array}{l}\text { Wage } \\
\text { employment }\end{array}$ & $\begin{array}{l}\text { Self- } \\
\text { employment }\end{array}$ \\
\hline Land security $\times$ & $0.060^{* * *}$ & 0.0160 & $0.056^{* * *}$ & $0.043^{* *}$ & 0.011 \\
year08 & $(0.019)$ & $(0.021)$ & $(0.019)$ & $(0.019)$ & $(0.012)$ \\
Land security $\times$ & 0.009 & -0.019 & 0.007 & 0.010 & -0.002 \\
year95 & $(0.01)$ & $(0.013)$ & $(0.014)$ & $(0.013)$ & $(0.009)$ \\
Land security & $-0.012^{*}$ & 0.005 & -0.002 & -0.005 & -0.001 \\
& $(0.007)$ & $(0.01)$ & $(0.009)$ & $(0.009)$ & $(0.006)$ \\
Year08 & -0.080 & -0.114 & -0.224 & -0.177 & 0.010 \\
& $(0.114)$ & $(0.153)$ & $(0.149)$ & $(0.144)$ & $(0.102)$ \\
Year95 & $-0.024^{* *}$ & $-0.027^{* *}$ & $-0.127^{* * *}$ & $-0.090^{* * *}$ & $-0.014^{*}$ \\
$R^{2}$ & $(0.009)$ & $(0.013)$ & $(0.013)$ & $(0.012)$ & $(0.008)$ \\
No. of obs. & 0.24 & 0.30 & 0.30 & 0.30 & 0.18 \\
\hline
\end{tabular}

Notes: (.) indicates standard error; significant at the $1 \%\left({ }^{* *}\right), 5 \%\left({ }^{* *}\right)$, and $10 \%\left({ }^{*}\right)$ levels. Each regression also includes the intercept, individual age and education level, land used by the household in log form, family financial assets in log form, village per capita income in log form, village consumption level in log form, and county fixed effects. Source: The following data sources, if not specifically stated, are from CHIP

Table 14 The effect of RLCL on employment outcomes of Men. Estimates by using a probit model

\begin{tabular}{llllll}
\hline Dependent variable & Employment & Farm & Off-farm & $\begin{array}{l}\text { Wage } \\
\text { employment }\end{array}$ & $\begin{array}{l}\text { Self- } \\
\text { employment }\end{array}$ \\
\hline Land security $\times$ & $0.048^{* *}$ & 0.019 & $0.071^{* * *}$ & $0.059^{* *}$ & 0.000 \\
year08 & $(0.02)$ & $(0.021)$ & $(0.023)$ & $(0.023)$ & $(0.014)$ \\
Land security $\times$ & $0.020^{* *}$ & 0.002 & 0.013 & 0.017 & 0.008 \\
year95 & $(0.009)$ & $(0.014)$ & $(0.016)$ & $(0.016)$ & $(0.01)$ \\
Land security & $-0.022^{* * *}$ & -0.005 & 0.000 & -0.007 & 0.009 \\
& $(0.007)$ & $(0.01)$ & $(0.01)$ & $(0.01)$ & $(0.007)$ \\
Year08 & $0.28^{* * *}$ & $-0.288^{*}$ & $0.328^{* *}$ & $0.400^{* *}$ & -0.079 \\
Year95 & $(0.109)$ & $(0.158)$ & $(0.163)$ & $(0.165)$ & $(0.104)$ \\
& $-0.065^{* * *}$ & $-0.129^{* * *}$ & $-0.277^{* * *}$ & $-0.231^{* * *}$ & $-0.032^{* * *}$ \\
$R^{2}$ & $(0.009)$ & $(0.013)$ & $(0.014)$ & $(0.014)$ & $(0.009)$ \\
No. of obs. & 0.27 & 0.28 & 0.24 & 0.20 & 0.20 \\
\hline Notes: (.) india & 31,308 & 31,482 & 31,034 & 30,998 & 28,726 \\
\hline
\end{tabular}

Notes: (.) indicates standard error; significant at the $1 \%\left({ }^{* *}\right), 5 \%(* *)$, and $10 \%(*)$ levels. Each regression also includes the intercept, individual age and education level, land used by the household in log form, family financial assets in log form, village per capita income in log form, village consumption level in log form, and county fixed effects. Source: The following data sources, if not specifically stated, are from CHIP 
Table 15 The effect of RLCL on employment outcomes of women

\begin{tabular}{|c|c|c|c|c|c|}
\hline Dependent variable & Employment & Farm & Off-farm & $\begin{array}{l}\text { Wage } \\
\text { employment }\end{array}$ & $\begin{array}{l}\text { Self- } \\
\text { employment }\end{array}$ \\
\hline $\begin{array}{l}\text { Land security } \times \\
\text { year08 }\end{array}$ & $\begin{array}{l}0.052^{* * *} \\
(0.019)\end{array}$ & $\begin{array}{l}-0.019 \\
(0.026)\end{array}$ & $\begin{array}{l}0.071 * * * \\
(0.025)\end{array}$ & $\begin{array}{l}0.048^{* *} \\
(0.024)\end{array}$ & $\begin{array}{l}0.010 \\
(0.014)\end{array}$ \\
\hline $\begin{array}{l}\text { Land security } \times \\
\text { year95 }\end{array}$ & $\begin{array}{l}0.001 \\
(0.012)\end{array}$ & $\begin{array}{l}0.005 \\
(0.014)\end{array}$ & $\begin{array}{l}-0.004 \\
(0.012)\end{array}$ & $\begin{array}{l}-0.005 \\
(0.011)\end{array}$ & $\begin{array}{l}-0.003 \\
(0.006)\end{array}$ \\
\hline Land security & $\begin{array}{l}-0.007 \\
(0.008)\end{array}$ & $\begin{array}{l}-0.009 \\
(0.01)\end{array}$ & $\begin{array}{l}0.002 \\
(0.009)\end{array}$ & $\begin{array}{l}0.005 \\
(0.009)\end{array}$ & $\begin{array}{l}0.000 \\
(0.005)\end{array}$ \\
\hline Year08 & $\begin{array}{l}-0.108 \\
(0.118)\end{array}$ & $\begin{array}{l}-0.073 \\
(0.153)\end{array}$ & $\begin{array}{l}-0.035 \\
(0.122)\end{array}$ & $\begin{array}{l}-0.027 \\
(0.114)\end{array}$ & $\begin{array}{l}0.013 \\
(0.054)\end{array}$ \\
\hline Year95 & $\begin{array}{l}-0.014 \\
(0.011)\end{array}$ & $\begin{array}{l}0.058^{* * *} \\
(0.013)\end{array}$ & $\begin{array}{l}-0.072^{* * *} \\
(0.011)\end{array}$ & $\begin{array}{l}-0.044^{* * *} \\
(0.01)\end{array}$ & $\begin{array}{l}-0.008 \\
(0.005)\end{array}$ \\
\hline Age & $\begin{array}{l}0.059^{* * *} \\
(0.001)\end{array}$ & $\begin{array}{l}0.052^{* * *} \\
(0.002)\end{array}$ & $\begin{array}{l}0.006^{* * *} \\
(0.001)\end{array}$ & $\begin{array}{l}0.004^{* * *} \\
(0.001)\end{array}$ & $\begin{array}{l}0.004^{* * *} \\
(0.000)\end{array}$ \\
\hline Age squared & $\begin{array}{l}-0.001^{* * *} \\
(0.000)\end{array}$ & $\begin{array}{l}-0.001^{* * *} \\
(0.000)\end{array}$ & $\begin{array}{l}0.000^{* * *} \\
(0.000)\end{array}$ & $\begin{array}{l}0.000^{* * *} \\
(0.000)\end{array}$ & $\begin{array}{l}0.000^{* * *} \\
(0.000)\end{array}$ \\
\hline Education level & $\begin{array}{l}-0.006^{* * *} \\
(0.001)\end{array}$ & $\begin{array}{l}-0.010^{* * *} \\
(0.001)\end{array}$ & $\begin{array}{l}0.004^{* * *} \\
(0.001)\end{array}$ & $\begin{array}{l}0.004^{* * *} \\
(0.001)\end{array}$ & $\begin{array}{l}0.001 * \\
(0.000)\end{array}$ \\
\hline Married & $\begin{array}{l}-0.019^{* *} \\
(0.008)\end{array}$ & $\begin{array}{l}0.084^{* * *} \\
(0.009)\end{array}$ & $\begin{array}{l}-0.103^{* * *} \\
(0.008)\end{array}$ & $\begin{array}{l}-0.118^{* * *} \\
(0.008)\end{array}$ & $\begin{array}{l}0.009^{* * *} \\
(0.004)\end{array}$ \\
\hline Log land & $\begin{array}{l}0.014^{* * *} \\
(0.003)\end{array}$ & $\begin{array}{l}0.048^{* * *} \\
(0.004)\end{array}$ & $\begin{array}{l}-0.033^{* * *} \\
(0.004)\end{array}$ & $\begin{array}{l}-0.019^{* * *} \\
(0.004)\end{array}$ & $\begin{array}{l}-0.017^{* * *} \\
(0.002)\end{array}$ \\
\hline Log asset & $\begin{array}{l}-0.001 \\
(0.002)\end{array}$ & $\begin{array}{l}0.000 \\
(0.002)\end{array}$ & $\begin{array}{l}-0.002 \\
(0.002)\end{array}$ & $\begin{array}{l}-0.012^{* * *} \\
(0.002)\end{array}$ & $\begin{array}{l}0.013^{* * *} \\
(0.001)\end{array}$ \\
\hline $\begin{array}{l}\text { Girls aged } 6 \text { or } \\
\text { younger }\end{array}$ & $\begin{array}{l}0.023^{* * *} \\
(0.005)\end{array}$ & $\begin{array}{l}0.041^{* * *} \\
(0.007)\end{array}$ & $\begin{array}{l}-0.017^{* * *} \\
(0.006)\end{array}$ & $\begin{array}{l}-0.015^{* *} \\
(0.006)\end{array}$ & $\begin{array}{l}-0.006^{*} \\
(0.003)\end{array}$ \\
\hline $\begin{array}{l}\text { Boys aged } 6 \text { or } \\
\text { younger }\end{array}$ & $\begin{array}{l}0.012^{* *} \\
(0.005)\end{array}$ & $\begin{array}{l}0.032^{* * *} \\
(0.007)\end{array}$ & $\begin{array}{l}-0.020 \\
(0.006)\end{array}$ & $\begin{array}{l}-0.020^{* * *} \\
(0.005)\end{array}$ & $\begin{array}{l}-0.005^{*} \\
(0.003)\end{array}$ \\
\hline Boys aged 7-14 & $\begin{array}{l}-0.011^{* * *} \\
(0.004)\end{array}$ & $\begin{array}{l}-0.011^{* *} \\
(0.005)\end{array}$ & $\begin{array}{l}0.000 \\
(0.004)\end{array}$ & $\begin{array}{l}-0.003 \\
(0.004)\end{array}$ & $\begin{array}{l}0.004^{*} \\
(0.002)\end{array}$ \\
\hline Girls aged 7-14 & $\begin{array}{l}-0.011^{* * *} \\
(0.004)\end{array}$ & $\begin{array}{l}-0.012^{* *} \\
(0.005)\end{array}$ & $\begin{array}{l}0.001 \\
(0.004)\end{array}$ & $\begin{array}{l}0.001 \\
(0.004)\end{array}$ & $\begin{array}{l}-0.001 \\
(0.002)\end{array}$ \\
\hline $\begin{array}{l}\text { Women aged } \\
15-25\end{array}$ & $\begin{array}{l}-0.001 \\
(0.003)\end{array}$ & $\begin{array}{l}-0.010^{* * *} \\
(0.004)\end{array}$ & $\begin{array}{l}0.009^{* * *} \\
(0.003)\end{array}$ & $\begin{array}{l}0.006^{* *} \\
(0.003)\end{array}$ & $\begin{array}{l}0.004^{* *} \\
(0.002)\end{array}$ \\
\hline $\begin{array}{l}\text { Men aged } \\
15-25\end{array}$ & $\begin{array}{l}0.004 \\
(0.003)\end{array}$ & $\begin{array}{l}-0.003 \\
(0.004)\end{array}$ & $\begin{array}{l}0.007^{*} \\
(0.004)\end{array}$ & $\begin{array}{l}0.005 \\
(0.003)\end{array}$ & $\begin{array}{l}0.003 \\
(0.002)\end{array}$ \\
\hline $\begin{array}{l}\text { Women aged } \\
26-39\end{array}$ & $\begin{array}{l}-0.056^{* * *} \\
(0.006)\end{array}$ & $\begin{array}{l}-0.084^{* * *} \\
(0.008)\end{array}$ & $\begin{array}{l}0.028^{* * *} \\
(0.006)\end{array}$ & $\begin{array}{l}0.027^{* * *} \\
(0.006)\end{array}$ & $\begin{array}{l}0.007^{* *} \\
(0.003)\end{array}$ \\
\hline $\begin{array}{l}\text { Men aged } \\
26-39\end{array}$ & $\begin{array}{l}-0.007 \\
(0.005)\end{array}$ & $\begin{array}{l}-0.004 \\
(0.007)\end{array}$ & $\begin{array}{l}-0.003 \\
(0.006)\end{array}$ & $\begin{array}{l}-0.002 \\
(0.005)\end{array}$ & $\begin{array}{l}0.005^{*} \\
(0.003)\end{array}$ \\
\hline $\begin{array}{l}\text { Women aged } \\
40-50\end{array}$ & $\begin{array}{l}-0.061^{* * *} \\
(0.007)\end{array}$ & $\begin{array}{l}-0.126^{* * *} \\
(0.009)\end{array}$ & $\begin{array}{l}0.065^{* * *} \\
(0.008)\end{array}$ & $\begin{array}{l}0.066^{* * *} \\
(0.007)\end{array}$ & $\begin{array}{l}0.002 \\
(0.004)\end{array}$ \\
\hline $\begin{array}{l}\text { Men aged } \\
40-50\end{array}$ & $\begin{array}{l}-0.021^{* * *} \\
(0.006)\end{array}$ & $\begin{array}{l}-0.013 \\
(0.009)\end{array}$ & $\begin{array}{l}-0.008 \\
(0.007)\end{array}$ & $\begin{array}{l}-0.002 \\
(0.007)\end{array}$ & $\begin{array}{l}-0.002 \\
(0.004)\end{array}$ \\
\hline $\begin{array}{l}\text { Women aged } \\
51-69\end{array}$ & $\begin{array}{l}-0.031^{* * *} \\
(0.006)\end{array}$ & $\begin{array}{l}-0.123^{* * *} \\
(0.009)\end{array}$ & $\begin{array}{l}0.092^{* * *} \\
(0.008)\end{array}$ & $\begin{array}{l}0.090^{* * *} \\
(0.007)\end{array}$ & $\begin{array}{l}0.011^{* * *} \\
(0.004)\end{array}$ \\
\hline Men aged 51-69 & $\begin{array}{l}0.030^{* * *} \\
(0.006)\end{array}$ & $\begin{array}{l}0.018^{* *} \\
(0.009)\end{array}$ & $\begin{array}{l}0.012^{*} \\
(0.007)\end{array}$ & $\begin{array}{l}0.017^{* *} \\
(0.007)\end{array}$ & $\begin{array}{l}-0.001 \\
(0.003)\end{array}$ \\
\hline $\begin{array}{l}\text { Women aged } \\
70 \text { over }\end{array}$ & $\begin{array}{l}-0.004 \\
(0.007)\end{array}$ & $\begin{array}{l}-0.013 \\
(0.009)\end{array}$ & $\begin{array}{l}0.009 \\
(0.008)\end{array}$ & $\begin{array}{l}0.006 \\
(0.008)\end{array}$ & $\begin{array}{l}0.001 \\
(0.004)\end{array}$ \\
\hline $\begin{array}{l}\text { Men aged } 70 \\
\text { over }\end{array}$ & $\begin{array}{l}-0.014^{*} \\
(0.009)\end{array}$ & $\begin{array}{l}-0.014 \\
(0.011)\end{array}$ & $\begin{array}{l}0.000 \\
(0.009)\end{array}$ & $\begin{array}{l}0.000 \\
(0.009)\end{array}$ & $\begin{array}{l}0.001 \\
(0.005)\end{array}$ \\
\hline $\begin{array}{l}\text { Log per capita } \\
\text { income }\end{array}$ & $\begin{array}{l}-0.013^{*} \\
(0.006)\end{array}$ & $\begin{array}{l}-0.016^{* *} \\
(0.008)\end{array}$ & $\begin{array}{l}0.003 \\
(0.007)\end{array}$ & $\begin{array}{l}-0.002 \\
(0.006)\end{array}$ & $\begin{array}{l}0.003 \\
(0.003)\end{array}$ \\
\hline $\begin{array}{l}\text { Log consumption } \\
\text { _level }\end{array}$ & $\begin{array}{l}0.185 \\
(0.215)\end{array}$ & $\begin{array}{l}0.005 \\
(0.275)\end{array}$ & $\begin{array}{l}0.179 \\
(0.218)\end{array}$ & $\begin{array}{l}0.227 \\
(0.205)\end{array}$ & $\begin{array}{l}-0.034 \\
(0.095)\end{array}$ \\
\hline$R^{2}$ & 0.19 & 0.31 & 0.27 & 0.26 & 0.09 \\
\hline No. of obs. & 28,813 & & & & \\
\hline
\end{tabular}

Notes: (.) indicates standard error; significant at the $1 \%\left(^{* * *}\right), 5 \%\left(^{* *}\right)$, and $10 \%\left({ }^{*}\right)$ levels. Each regression result be showed with 2002 and 2008 data by using both types of definitions of treatment. Source: The following data sources, if not specifically stated, are from CHIP 
Table 16 The effect of RLCL on employment outcomes of men

\begin{tabular}{|c|c|c|c|c|c|}
\hline Dependent variable & Employment & Farm & Off-farm & $\begin{array}{l}\text { Wage } \\
\text { employment }\end{array}$ & $\begin{array}{l}\text { Self- } \\
\text { employment }\end{array}$ \\
\hline $\begin{array}{l}\text { Land security } \times \\
\text { year08 }\end{array}$ & $\begin{array}{l}0.028^{*} \\
(0.015)\end{array}$ & $\begin{array}{l}-0.062^{* *} \\
(0.026)\end{array}$ & $\begin{array}{l}0.09^{* * *} \\
(0.027)\end{array}$ & $\begin{array}{l}0.054^{* *} \\
(0.027)\end{array}$ & $\begin{array}{l}0.025 \\
(0.019)\end{array}$ \\
\hline $\begin{array}{l}\text { Land security } \times \\
\text { year95 }\end{array}$ & $\begin{array}{l}0.011 \\
(0.011)\end{array}$ & $\begin{array}{l}0.003 \\
(0.016)\end{array}$ & $\begin{array}{l}0.007 \\
(0.015)\end{array}$ & $\begin{array}{l}-0.006 \\
(0.015)\end{array}$ & $\begin{array}{l}0.015^{*} \\
(0.008)\end{array}$ \\
\hline Land security & $\begin{array}{l}-0.011 \\
(0.007)\end{array}$ & $\begin{array}{l}-0.006 \\
(0.012)\end{array}$ & $\begin{array}{l}-0.006 \\
(0.012)\end{array}$ & $\begin{array}{l}0.005 \\
(0.012)\end{array}$ & $\begin{array}{l}-0.005 \\
(0.006)\end{array}$ \\
\hline Year08 & $\begin{array}{l}0.233^{* *} \\
(0.111)\end{array}$ & $\begin{array}{l}-0.243 \\
(0.175)\end{array}$ & $\begin{array}{l}0.476^{* * *} \\
(0.156)\end{array}$ & $\begin{array}{l}0.504^{* * *} \\
(0.154)\end{array}$ & $\begin{array}{l}-0.042 \\
(0.075)\end{array}$ \\
\hline Year95 & $\begin{array}{l}-0.033^{* * *} \\
(0.010)\end{array}$ & $\begin{array}{l}0.222^{* * *} \\
(0.015)\end{array}$ & $\begin{array}{l}-0.254^{* * *} \\
(0.014)\end{array}$ & $\begin{array}{l}-0.190^{* * *} \\
(0.014)\end{array}$ & $\begin{array}{l}-0.033^{* * *} \\
(0.007)\end{array}$ \\
\hline Age & $\begin{array}{l}0.049^{* * *} \\
(0.001)\end{array}$ & $\begin{array}{l}0.014^{* * *} \\
(0.001)\end{array}$ & $\begin{array}{l}0.035^{* * *} \\
(0.001)\end{array}$ & $\begin{array}{l}0.030^{* * *} \\
(0.001)\end{array}$ & $\begin{array}{l}0.008^{* * *} \\
(0.001)\end{array}$ \\
\hline Age squared & $\begin{array}{l}-0.001^{* * *} \\
(0.000)\end{array}$ & $\begin{array}{l}0.000^{* *} \\
(0.000)\end{array}$ & $\begin{array}{l}-0.001^{* * *} \\
(0.000)\end{array}$ & $\begin{array}{l}0.000^{* * *} \\
(0.000)\end{array}$ & $\begin{array}{l}0.000^{* * *} \\
(0.000)\end{array}$ \\
\hline Education level & $\begin{array}{l}-0.007^{* * *} \\
(0.001)\end{array}$ & $\begin{array}{l}-.0130^{* * *} \\
(0.001)\end{array}$ & $\begin{array}{l}0.006^{* * *} \\
(0.001)\end{array}$ & $\begin{array}{l}0.005^{* * *} \\
(0.001)\end{array}$ & $\begin{array}{l}0.000 \\
(0.001)\end{array}$ \\
\hline Married & $\begin{array}{l}0.021^{* * *} \\
(0.006)\end{array}$ & $\begin{array}{l}-0.013 \\
(0.008)\end{array}$ & $\begin{array}{l}0.034^{* * *} \\
(0.008)\end{array}$ & $\begin{array}{l}0.006 \\
(0.008)\end{array}$ & $\begin{array}{l}0.026^{* * *} \\
(0.004)\end{array}$ \\
\hline Log land & $\begin{array}{l}0.006^{*} \\
(0.003)\end{array}$ & $\begin{array}{l}0.054^{* * *} \\
(0.004)\end{array}$ & $\begin{array}{l}-0.049^{* * *} \\
(0.004)\end{array}$ & $\begin{array}{l}-0.028^{* * *} \\
(0.005)\end{array}$ & $\begin{array}{l}-0.025^{* * *} \\
(0.003)\end{array}$ \\
\hline Log asset & $\begin{array}{l}-0.004^{* * *} \\
(0.002)\end{array}$ & $\begin{array}{l}0.004^{*} \\
(0.002)\end{array}$ & $\begin{array}{l}-0.008^{* * *} \\
(0.002)\end{array}$ & $\begin{array}{l}-0.029^{* * *} \\
(0.002)\end{array}$ & $\begin{array}{l}0.027^{* * *} \\
(0.002)\end{array}$ \\
\hline $\begin{array}{l}\text { Girls aged } 6 \text { or } \\
\text { younger }\end{array}$ & $\begin{array}{l}0.021^{* * *} \\
(0.005)\end{array}$ & $\begin{array}{l}0.009 \\
(0.008)\end{array}$ & $\begin{array}{l}0.012^{*} \\
(0.007)\end{array}$ & $\begin{array}{l}0.014^{*} \\
(0.007)\end{array}$ & $\begin{array}{l}-0.002 \\
(0.004)\end{array}$ \\
\hline $\begin{array}{l}\text { Boys aged } 6 \text { or } \\
\text { younger }\end{array}$ & $\begin{array}{l}0.011^{* *} \\
(0.005)\end{array}$ & $\begin{array}{l}-0.006 \\
(0.007)\end{array}$ & $\begin{array}{l}0.017^{* *} \\
(0.007)\end{array}$ & $\begin{array}{l}0.017^{* *} \\
(0.007)\end{array}$ & $\begin{array}{l}-0.004 \\
(0.004)\end{array}$ \\
\hline Boys aged 7-14 & $\begin{array}{l}-0.012^{* * *} \\
(0.004)\end{array}$ & $\begin{array}{l}-0.022^{* * *} \\
(0.006)\end{array}$ & $\begin{array}{l}0.010^{* *} \\
(0.005)\end{array}$ & $\begin{array}{l}0.008 \\
(0.005)\end{array}$ & $\begin{array}{l}0.007^{* *} \\
(0.003)\end{array}$ \\
\hline Girls aged 7-14 & $\begin{array}{l}-0.016^{* * *} \\
(0.004)\end{array}$ & $\begin{array}{l}-0.015^{* * *} \\
(0.006)\end{array}$ & $\begin{array}{l}-0.001 \\
(0.005)\end{array}$ & $\begin{array}{l}-0.004 \\
(0.005)\end{array}$ & $\begin{array}{l}0.004 \\
(0.003)\end{array}$ \\
\hline $\begin{array}{l}\text { Women aged } \\
15-25\end{array}$ & $\begin{array}{l}-0.005^{*} \\
(0.003)\end{array}$ & $\begin{array}{l}-0.002 \\
(0.004)\end{array}$ & $\begin{array}{l}-0.003 \\
(0.004)\end{array}$ & $\begin{array}{l}-0.004 \\
(0.004)\end{array}$ & $\begin{array}{l}-0.001 \\
(0.002)\end{array}$ \\
\hline Men aged 15-25 & $\begin{array}{l}0.008^{* * *} \\
(0.003)\end{array}$ & $\begin{array}{l}-0.003 \\
(0.004)\end{array}$ & $\begin{array}{l}0.011^{* * *} \\
(0.004)\end{array}$ & $\begin{array}{l}0.006 \\
(0.004)\end{array}$ & $\begin{array}{l}0.002 \\
(0.002)\end{array}$ \\
\hline $\begin{array}{l}\text { Women aged } \\
\text { 26-39 }\end{array}$ & $\begin{array}{l}-0.024^{* * *} \\
(0.005)\end{array}$ & $\begin{array}{l}-0.028^{* * *} \\
(0.007)\end{array}$ & $\begin{array}{l}0.004 \\
(0.007)\end{array}$ & $\begin{array}{l}0.002 \\
(0.007)\end{array}$ & $\begin{array}{l}0.013^{* * *} \\
(0.004)\end{array}$ \\
\hline Men aged 26-39 & $\begin{array}{l}-0.019^{* * *} \\
(0.004)\end{array}$ & $\begin{array}{l}-0.013^{* *} \\
(0.006)\end{array}$ & $\begin{array}{l}-0.006 \\
(0.006)\end{array}$ & $\begin{array}{l}-0.003 \\
(0.006)\end{array}$ & $\begin{array}{l}-0.008^{* *} \\
(0.003)\end{array}$ \\
\hline $\begin{array}{l}\text { Women aged } \\
40-50\end{array}$ & $\begin{array}{l}-0.005 \\
(0.006)\end{array}$ & $\begin{array}{l}-0.025^{* * *} \\
(0.009)\end{array}$ & $\begin{array}{l}0.02^{* *} \\
(0.008)\end{array}$ & $\begin{array}{l}0.019^{* *} \\
(0.008)\end{array}$ & $\begin{array}{l}0.006 \\
(0.005)\end{array}$ \\
\hline Men aged 40-50 & $\begin{array}{l}-0.063^{* * *} \\
(0.006)\end{array}$ & $\begin{array}{l}-0.063^{* * *} \\
(0.009)\end{array}$ & $\begin{array}{l}0.000 \\
(0.008)\end{array}$ & $\begin{array}{l}0.012 \\
(0.008)\end{array}$ & $\begin{array}{l}-0.014^{* * *} \\
(0.005)\end{array}$ \\
\hline $\begin{array}{l}\text { Women aged } \\
51-69\end{array}$ & $\begin{array}{l}0.022^{* * *} \\
(0.006)\end{array}$ & $\begin{array}{l}-0.027^{* * *} \\
(0.009)\end{array}$ & $\begin{array}{l}0.049^{* * *} \\
(0.008)\end{array}$ & $\begin{array}{l}0.049^{* * *} \\
(0.008)\end{array}$ & $\begin{array}{l}0.010^{* *} \\
(0.005)\end{array}$ \\
\hline Men aged 51-69 & $\begin{array}{l}-0.013^{* *} \\
(0.006)\end{array}$ & $\begin{array}{l}-0.068^{* * *} \\
(0.009)\end{array}$ & $\begin{array}{l}0.055^{* * *} \\
(0.008)\end{array}$ & $\begin{array}{l}0.065^{* * *} \\
(0.008)\end{array}$ & $\begin{array}{l}-0.009^{* *} \\
(0.005)\end{array}$ \\
\hline $\begin{array}{l}\text { Women aged } \\
70 \text { over }\end{array}$ & $\begin{array}{l}0.008 \\
(0.006)\end{array}$ & $\begin{array}{l}-0.009 \\
(0.009)\end{array}$ & $\begin{array}{l}0.017^{*} \\
(0.009)\end{array}$ & $\begin{array}{l}0.014 \\
(0.009)\end{array}$ & $\begin{array}{l}0.000 \\
(0.005)\end{array}$ \\
\hline Men aged 70 over & $\begin{array}{l}-0.013^{*} \\
(0.008)\end{array}$ & $\begin{array}{l}-0.014 \\
(0.012)\end{array}$ & $\begin{array}{l}0.002 \\
(0.011)\end{array}$ & $\begin{array}{l}-0.004 \\
(0.011)\end{array}$ & $\begin{array}{l}0.008 \\
(0.007)\end{array}$ \\
\hline $\begin{array}{l}\text { Ln per capita } \\
\text { income }\end{array}$ & $\begin{array}{l}-0.016^{* * *} \\
(0.006)\end{array}$ & $\begin{array}{l}-0.025^{* * *} \\
(0.008)\end{array}$ & $\begin{array}{l}0.009 \\
(0.008)\end{array}$ & $\begin{array}{l}0.002 \\
(0.008)\end{array}$ & $\begin{array}{l}0.011^{* *} \\
(0.005)\end{array}$ \\
\hline $\begin{array}{l}\text { Log } \\
\text { consumption_level }\end{array}$ & $\begin{array}{l}-0.322 \\
(0.202)\end{array}$ & $\begin{array}{l}0.441 \\
(0.317)\end{array}$ & $\begin{array}{l}-0.763^{* * *} \\
(0.281)\end{array}$ & $\begin{array}{l}-0.691^{* *} \\
(0.278)\end{array}$ & $\begin{array}{l}0.027 \\
(0.129)\end{array}$ \\
\hline$R^{2}$ & 0.20 & 0.27 & 0.28 & 0.23 & 0.13 \\
\hline No. of obs. & 31,580 & & & & \\
\hline
\end{tabular}

Notes: (.) indicates standard error; significant at the $1 \%\left(^{* * *}\right), 5 \%\left(^{* *}\right)$, and $10 \%\left({ }^{*}\right)$ levels. Each regression result be showed with 2002 and 2008 data by using both types of definitions of treatment. Source: The following data sources, if not specifically stated, are from CHIP 
Table 17 The effect of RLCL on employment outcomes of Women. Estimates by using cluster standard errors at village level

\begin{tabular}{llllll}
\hline Dependent variable & Employment & Farm & Off-farm & $\begin{array}{l}\text { Wage } \\
\text { employment }\end{array}$ & $\begin{array}{l}\text { Self- } \\
\text { employment }\end{array}$ \\
\hline Land security $\times$ & $0.058^{* *}$ & -0.013 & $0.071^{* *}$ & $0.054^{* *}$ & 0.011 \\
year08 & $(0.025)$ & $(0.028)$ & $(0.028)$ & $(0.026)$ & $(0.010)$ \\
Land security $\times$ & 0.007 & 0.010 & -0.003 & 0.001 & -0.002 \\
year95 & $(0.014)$ & $(0.017)$ & $(0.014)$ & $(0.014)$ & $(0.006)$ \\
Land security & -0.013 & -0.015 & 0.001 & -0.002 & -0.001 \\
& $(0.009)$ & $(0.013)$ & $(0.011)$ & $(0.010)$ & $(0.005)$ \\
Year08 & -0.103 & -0.068 & -0.035 & -0.021 & 0.014 \\
& $(0.135)$ & $(0.199)$ & $(0.164)$ & $(0.145)$ & $(0.071)$ \\
Year95 & -0.016 & $0.057^{* * *}$ & $-0.073^{* * *}$ & $-0.048^{* * *}$ & -0.008 \\
$R^{2}$ & $(0.012)$ & $(0.015)$ & $(0.012)$ & $(0.011)$ & $(0.005)$ \\
No. of obs. & 0.19 & 0.31 & 0.27 & 0.26 & 0.09 \\
\hline
\end{tabular}

Notes: (.) indicates standard error; significant at the $1 \%\left({ }^{* * *}\right), 5 \%\left({ }^{* *}\right)$, and $10 \%\left({ }^{*}\right)$ levels. Each regression also includes the intercept, individual age and education level, land used by the household in log form, family financial assets in log form, village per capita income in log form, village consumption level in log form, and county fixed effects. Source: The following data sources, if not specifically stated, are from CHIP

Table 18 The effect of RLCL on employment outcomes of Men. Estimates by using cluster standard errors at village level

\begin{tabular}{llllll}
\hline Dependent variable & Employment & Farm & Off-farm & $\begin{array}{l}\text { Wage } \\
\text { employment }\end{array}$ & $\begin{array}{l}\text { Self- } \\
\text { employment }\end{array}$ \\
\hline Land security $\times$ & $0.041^{*}$ & $-0.059^{*}$ & $0.100^{* * *}$ & $0.074^{* *}$ & 0.024 \\
year08 & $(0.023)$ & $(0.031)$ & $(0.037)$ & $(0.037)$ & $(0.019)$ \\
Land security $\times$ year95 & 0.022 & 0.018 & 0.004 & 0.010 & -0.002 \\
& $(0.015)$ & $(0.024)$ & $(0.021)$ & $(0.02)$ & $(0.01)$ \\
Land security & $-0.025^{* * *}$ & -0.026 & 0.001 & -0.008 & 0.011 \\
& $(0.009)$ & $(0.016)$ & $(0.016)$ & $(0.016)$ & $(0.008)$ \\
Year08 & $0.289^{* *}$ & -0.153 & 0.442 & $0.528^{* *}$ & -0.133 \\
Year95 & $(0.147)$ & $(0.293)$ & $(0.279)$ & $(0.268)$ & $(0.114)$ \\
$R^{2}$ & $-0.031^{* * *}$ & $0.210^{* * *}$ & $-0.241^{* * *}$ & $-0.193^{* * *}$ & $-0.020^{* *}$ \\
No. of obs. & $(0.011)$ & $(0.024)$ & $(0.022)$ & $(0.021)$ & $(0.008)$ \\
\hline
\end{tabular}

Notes: (.) indicates standard error; significant at the $1 \%\left(^{* * *}\right), 5 \%\left(^{* *}\right)$, and $10 \%\left({ }^{*}\right)$ levels. Each regression also includes the intercept, individual age and education level, land used by the household in log form, family financial assets in log form, village per capita income in log form, village consumption level in log form, and county fixed effects. Source: The following data sources, if not specifically stated, are from CHIP

\section{Acknowledgements}

This research work was carried out with financial and scientific support from the Partnership for Economic Policy (PEP) (www.pep-net.org) with funding from the Department for International Development (DFID) of the UK (or UK Aid), and the Government of Canada through the International Development Research Center (IDRC). The authors are also grateful to Professor Marcelo Bergolo and Manuel Paradis for the technical support and guidance, as well as to Professor Luca Tiberti for the valuable comments and suggestions. The authors would also like to thank the helpful remarks from an anonymous referee and the editor.

Responsible editor: Hartmut F. Lehmann

\section{Competing interests}

The IZA Journal of Development and Migration is committed to the IZA Guiding Principles of Research Integrity. The authors declare that they have observed these principles.

\section{Publisher's Note}


Received: 11 August 2017 Accepted: 27 November 2017

Published online: 10 May 2018

\section{References}

Angrist JD, Krueger AB. Empirical strategies in labor economics. In: Ashenfelter O, Card D, editors. Handbook of labor economics, vol. 3A. Amsterdam: Elsevier; 1999. p. 1277-366.

Benjamin D, Brandt L, Rozelle S. Aging, wellbeing, and social security in rural northern China. Popul Dev Rev. 2000;26:89-116.

Besley T. Property rights and investment incentives: theory and evidence from Ghana. J Polit Econ. 1995;103(5): 903-37.

Brandt L, Huang, Li G, Rozelle S. Land rights in China: facts, fictions and issues. The China Journal. 2002;47:67-97.

Burgess, R. (1998). Market incompleteness and nutritional status in rural China. In Paper delivered at the International Conference on Land Tenure and Agricultural Performance in Rural China, Beijing, China.

Carter, M. R., \& Yao, Y. (1999). Specialization without regret: transfer rights, agricultural productivity, and investment in an industrializing economy (World Bank policy research working paper no. 2202).

Chan A, Senser RA. China's troubled workers. Foreign Affairs. 1997;76(2):104-17.

Chang $H Q$, MacPhail F, Dong XY. The feminization of labor and the gender work-time gap in rural China. Fem Econ. 2011;17(4):93-124.

Cheng YS, Tsang SK. Agricultural land reform in a mixed system: the Chinese experience of 1984-1994. China Information. 1996;10:44-74.

De Brauw A, Huang J, Rozelle S, Zhang L, Zhang Y. The evolution of China's rural labor market during the reforms. J Comp Econ. 2002;30:353-529.

De La Rupelle, M., Deng, Q., Shi, L., \& Vendryes, T. (2009). Land rights insecurity and temporary migration in rural China (discussion paper no. 4668).

Deininger K, Jin S. The impact of property rights on households'investment, risk coping, and policy preferences: evidence from China. Econ Dev Cult Chang. 2003;51(4):851-82.

Deininger, K., Jin, S., \& Xian, Z. (2004). Implementing China's new land law: evidence and policy lessons.

Deininger, K., Jin, S.Q., \& Fang, X. (2012). Moving off the farm: land institutions to facilitate structural transformation and agricultural productivity growth in China. (World Bank policy research working paper no. 5949).

Dong XY. Two-tier land tenure system and sustained economic growth in post-1978 rural China. World Dev. 1996;24:915-28.

Duncan J, Ping L. Women and land tenure in China: a study of women's land rights in Dongfang county. Hainan Province: Rural Development Institute Report; 2001.

Field E. Entitled to work: urban tenure security and labor supply in Peru. Q J Econ. 2007;4(122):1561-602.

Goldstein M, Udry C. The profits of power: land rights and agricultural investment in Ghana. J Polit Econ. 2008; 116(6):981-1022

Jacoby H, Li G, Rozelle S. Hazards of expropriation: tenure insecurity and investment in rural China. Am Econ Rev. 2002;92(5):1420-47.

Knight J, Song L. Chinese peasant choices: migration, rural industry or farming. Oxf Dev Stud. 2003;31(2):123-47.

Kung JK. Egalitarianism, subsistence provision, and work incentives in China's agricultural collectives. World Dev. 1994;22(2):175-87.

Kung JK. Off-farm labor markets and the emergence of land rental markets in rural China. J Comp Econ. 2002; 30(2):395-414.

Kung JK, Lee YF. So what if there is income inequality? The distributive consequence of non farm employment in rural China. Econ Dev Cult Chang. 2001;50(1):19-46.

Li G. The economics of land tenure and property rights in China's agricultural sector. Stanford University: Unpublished Ph.D. dissertation; 1999.

Li S. Women's employment and income. Chinese Social Science. 2001;2001(3):56-69.

Li P. Rural land tenure reforms in China: issues, regulations and prospects for additional reform. Land Reform, Land Settlement, and Cooperatives. 2003;11(3):59-72.

Li Y, Xi YS. Married women's rights to land in China's traditional farming areas. Journal of Contemporary China. 2006; 15(49):621-36.

Li G, Rozelle S, Brandt L. Tenure, land rights, and farmer investment incentives in China. Agric Econ. 1998;19(1):63-71.

Li Q, Huang J, Luo R, Liu C. China's labor transition and the future of China's rural wages and employment. China \& World Economy. 2013;21(3):4-24.

Liaw HR. Women's land rights in rural China: transforming existing laws into a source of property rights. Pacific Rim Law \& Policy Journal. 2008;17(1):237-65.

Lin JY. Rural reforms and agricultural growth in China. Am Econ Rev. 1992;82(1):34-51.

Lohmar B. Land tenure insecurity and labor allocation in rural China. Nashville, TN: Paper presented at the American Agricultural Economics Association Annual Meeting; 1999.

Lohmar B, Zhang ZX, Somwaru A. Land rental market development and agricultural production in China. Chicago, IL: Paper presented at the American Agricultural Economics Association Annual Meeting; 2001.

Maurer-Fazio M. Earnings and education in China's transition to a market economy survey evidence from 1989 and 1992. China Econ Rev. 1999;10(1):17-40.

Mu, R., and Giles, J. (2014). Village political economy, land tenure insecurity, and the rural to urban migration decision: evidence from China. World Bank Policy Research Working Paper, (7080).

Mullan K, Grosjean P, Kontoleon A. Land tenure arrangements and rural-urban migration in China. World Dev. 2011;39(1):123-33.

Mullen, K., P. Grosjean, and A. Kontoleon. 2008. Land tenure arrangements and rural urban migration in China. Environmental Economy and Policy Research Discussion Paper Series, Number 37. University of Cambridge, Department of Land Economy, UK.

Rozelle S, Li G. Village leaders and land-rights formation in China. Am Econ Rev. 1998;88(2):433-8. 
Rozelle S, Guo L, Shen M, Hughart A, Giles J. Leaving China's farms: survey results of new paths and remaining hurdles to rural migration. The China Quarterly. 1999;158(158):367-93.

Rozelle S, Brandt L, Guo L, Huang J. Land rights in China: facts, fictions, and issues. China Journal. 2002;47(1):67-97.

Shi X, Heerink N, Qu F. Choices between different off-farm employment sub-categories: an empirical analysis for Jiangxi Province, China. China Econ Rev. 2007;18:438-55.

Solinger DJ. Citizenship issues in China's internal migration: comparisons with Germany and Japan. Political Science Quarterly. 1999;114(3):455-78.

Song, Y. \& Jiggins, J. (2000, January). Feminization of agriculture and related issues: two cases study in marginal rural area in China. Paper presented at the European Conference on Agricultural and Rural Development in China (ECARDC), Leiden, Holland

Tao R, Xu Z. Urbanization, rural land system and social security for migrants in China. J Dev Stud. 2007;43(7):1301-20

Wang YX. De-intensification and the feminization of farming in China. Gend Technol Dev. 1999;3(2):189-214.

Wang X, Huang J, Zhang L, Rozelle S. The rise of migration and the fall of self employment in rural China's labor market. China Econ Rev. 2011;22:573-84.

Zhang L. Land rights in twenty-first century: the evolution of tenure security, transfer and control rights in rural China, working paper. Center for Chinese Agricultural Policy, Institutefor geographical sciences and natural resource research. Beijing: Chinese Academy of Sciences; 2001.

Zhao Y. Leaving the countryside: rural-to-urban migration decisions in China. Am Econ Rev. 1999;89(2):281-6.

Submit your manuscript to a SpringerOpen ${ }^{\odot}$ journal and benefit from:

- Convenient online submission

- Rigorous peer review

- Open access: articles freely available online

- High visibility within the field

- Retaining the copyright to your article

Submit your next manuscript at $\gg$ springeropen.com 